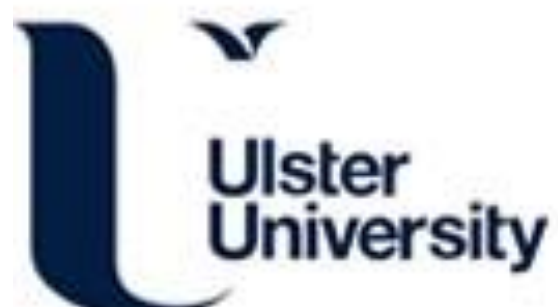

\section{The influence of target stoichiometry on early cell adhesionof co-sputtered calcium-phosphate surfaces}

Boyd, A., O'Kane, C., O'Hare, P., Burke, GA., \& Meenan, BJ. (2013). The influence of target stoichiometry on early cell adhesionof co-sputtered calcium-phosphate surfaces. Journal of Materials Science: Materials in Medicine, 24, 2845-2861. https://doi.org/10.1007/s10856-013-5021-3

Link to publication record in Ulster University Research Portal

\section{Published in:}

Journal of Materials Science: Materials in Medicine

Publication Status:

Published (in print/issue): 01/01/2013

DOI:

10.1007/s10856-013-5021-3

\section{Document Version}

Publisher's PDF, also known as Version of record

\section{General rights}

Copyright for the publications made accessible via Ulster University's Research Portal is retained by the author(s) and / or other copyright owners and it is a condition of accessing these publications that users recognise and abide by the legal requirements associated with these rights.

\section{Take down policy}

The Research Portal is Ulster University's institutional repository that provides access to Ulster's research outputs. Every effort has been made to ensure that content in the Research Portal does not infringe any person's rights, or applicable UK laws. If you discover content in the Research Portal that you believe breaches copyright or violates any law, please contact pure-support@ulster.ac.uk. 


\title{
The influence of target stoichiometry on early cell adhesion of co-sputtered calcium-phosphate surfaces
}

\author{
A. R. Boyd • C. O'Kane · P. O'Hare • \\ G. A. Burke $\cdot$ B. J. Meenan
}

Received: 16 May 2013/Accepted: 26 July 2013/Published online: 7 August 2013

(C) Springer Science+Business Media New York 2013

\begin{abstract}
The nature of the initial interaction between calcium phosphate $(\mathrm{Ca}-\mathrm{P})$ thin films and osteoblasts can be influenced by a number of different properties including the phase, crystallinity, stoichiometry and composition of the surface. There is still a strong interest in developing and studying $\mathrm{Ca}-\mathrm{P}$ surfaces that have the ability to accurately control the osteoblast response. Radio frequency (RF) magnetron sputtering is a technique that allows for accurate control of the properties of deposited Ca-P coatings and has been studied extensively because of this fact. In this work, $\mathrm{Ca}-\mathrm{P}$ coatings were co-deposited using RF magnetron sputtering in order to study the effect of changing the target stoichiometry on the initial in vitro behavior of MG63 osteoblast-like cells. The samples produced were analysed both as-deposited and after thermal annealing to $500{ }^{\circ} \mathrm{C}$. After annealing XPS analyses of the samples co-deposited using tricalcium phosphate (TCP) materials gave a $\mathrm{Ca} / \mathrm{P}$ ratio of $1.71 \pm 0.01$, as compared to those co-deposited from hydroxyapatite (HA) materials, with a $\mathrm{Ca} / \mathrm{P}$ of $1.82 \pm 0.06$. In addition to this, the curve fitted XPS data indicated the presence of low levels of carbonate in the coatings. Despite this the XRD results for all of the annealed coatings were shown to be characteristic of pure HA with a preferred 002 orientation. The atomic force microscopy results also highlighted that both types of coatings had surface features of a similar size (200-220 nm). Both surfaces exhibited a degree of surface degradation, even after $1 \mathrm{~h}$ of cell culture. However, the TCP derived surfaces showed an enhanced
\end{abstract}

\footnotetext{
A. R. Boyd $(\bowtie) \cdot$ C. O'Kane · P. O'Hare ·

G. A. Burke · B. J. Meenan

Nanotechnology and Integrated Bioengineering Centre (NIBEC),

School of Engineering, University of Ulster, Shore Road,

Newtownabbey, Co. Antrim BT37 0QB, Northern Ireland, UK

e-mail: ar.boyd@ulster.ac.uk
}

osteoblastic cell response in terms of cell adhesion and cell proliferation in the earlier stages of cell culture than the surfaces deposited from HA. An improvement in the initial cell attachment and a potential for increased cell proliferation rates is viewed as a highly advantageous result in relation to controlling the osteoblast response on these surfaces.

\section{Introduction}

The nature of the interaction of a biomaterial and a physiological environment will obviously be mediated by the outermost surface properties exhibited by that material. Due to their inherent bioactivity, calcium phosphate $(\mathrm{Ca}-\mathrm{P})$ bioceramics, in particular hydroxyapatite $\left[\mathrm{HA}-\mathrm{Ca}_{10}\left(\mathrm{PO}_{4}\right)_{6}(\mathrm{OH})_{2}\right]$ and alpha-tri-calcium phosphate $\left[\mathrm{TCP}-\mathrm{Ca}_{3}\left(\mathrm{PO}_{4}\right)_{2}\right]$, have been utilised as thin film coatings for controlling osteoblast function and have been studied extensively for such purposes [1]. In order to control the properties of these surfaces a range of different techniques have been utilised to this end, including, plasma spraying, pulsed laser deposition, electrophoretic deposition, sol-gel deposition, biomimetic methods, co-blasting and radio frequency (RF) magnetron sputtering [1-5]. Of these techniques RF magnetron sputtering has been shown to be a particularly useful technique for the deposition of $\mathrm{Ca}-\mathrm{P}$ coatings due to the ability of the technique to provide greater control of the coating's properties and improved biological performance [1, 6-8].

To date most of the work reporting on the deposition of $\mathrm{Ca}-\mathrm{P}$ coatings by RF magnetron sputtering have utilised a single $\mathrm{Ca}-\mathrm{P}$ target. These studies have addressed the influence of the different sputtering process parameters on the properties of the deposited coatings, such as discharge power level $[9,10]$, process gas pressure [11, 12], thermal annealing [10,13], initial target stoichiometry [14, 15] and target composition $[16,17]$. However, recent studies have 
demonstrated how co-sputtering from two targets could be successfully applied to produce silicon [18], zirconia [19], tantalum [20] or silver [21] doped HA surfaces. Further studies have also examined how co-sputtering from three HA targets can influence the properties of the resultant surfaces and their potential biofunctionality with associated annealing of the coatings $[6,13]$. Other work has examined the influence of the process gas pressure on the properties of co-deposited Ca-P surfaces [11]. Despite this there relatively few other reports available on the utilisation of multiple $\mathrm{Ca}-\mathrm{P}$ targets to co-sputter coatings with the appropriate surface functionality and there is a deficit of knowledge and understanding in this regard. Some earlier studies, albeit using a single target, have examined the influence of target stoichiometry on the properties of the resultant coatings [15], but to date the co-deposition of such materials has not been addressed in any great detail in the literature $[14,22]$. Several other studies have investigated the in vitro and in vivo performance of sputter deposited coatings from single target sputtering systems, whereby the target stoichiometry has been the principle matter of interest [23]. However, to the best knowledge of the authors there are no published studies which have examined the in vitro performance of co-sputtered $\mathrm{Ca}-\mathrm{P}$ coatings from targets of different stoichiometry. Therefore, the present work was undertaken in order to study the codeposition of $\mathrm{Ca}-\mathrm{P}$ coatings from multiple targets of different stoichiometries and report on their potential utility for controlling osteoblast function, in vitro. In particular, the influence of the target stoichiometry on the properties of $\mathrm{Ca}-\mathrm{P}$ coatings produced at a low discharge power level $(150 \mathrm{~W})$ was investigated. A low discharge power level was chosen for this study as the quality and consistency of the targets used could be guaranteed throughout the sputter deposition runs. All of the coatings produced were characterised in the as-deposited (AD) state and after post deposition annealing (PDA) at $500{ }^{\circ} \mathrm{C}$ using fourier transform infrared spectroscopy (FTIR), X-ray diffraction (XRD), X-ray photoelectron spectroscopy (XPS), atomic force microscopy (AFM) and stylus profilometry. Early cell adhesion events were also studied, in vitro, to screen the initial interactions of osteoblast-like cells with the different surfaces produced. This study represents one of the first attempts to study the effects of stoichiometry on the initial in vitro behavior of co-deposited $\mathrm{Ca}-\mathrm{P}$ materials.

\section{Materials and methods}

For this study, titanium was initially sputter deposited onto silicon substrates to provide a normalised polycrystalline titanium surface. Subsequently, Ca-P coatings were deposited onto these polycrystalline titanium layers and
Table 1 Details of the different $\mathrm{Ca}-\mathrm{P}$ precursor powders

\begin{tabular}{lll}
\hline Material name & Chemical formula & Theoretical Ca/P ratio \\
\hline HA & $\mathrm{Ca}_{10}\left(\mathrm{PO}_{4}\right)_{6} \mathrm{OH}_{2}$ & 1.67 \\
TCP & $\mathrm{Ca}_{3}\left(\mathrm{PO}_{4}\right)$ & 1.5 \\
\hline
\end{tabular}

thermally annealed after deposition. The calcium phosphate powders to be sputter deposited were hydroxyapatite [HA-Ca ${ }_{10}\left(\mathrm{PO}_{4}\right)_{6}(\mathrm{OH})_{2}$ (Plasma Biotal Captal-R)], and alphatricalcium phosphate $\left[\mathrm{TCP}-\mathrm{Ca}_{3}\left(\mathrm{PO}_{4}\right)_{2}\right.$ (Sigma Aldrich Ltd.)] as detailed in Table 1.

\subsection{Substrate preparation}

Coupons of silicon $(15 \mathrm{~mm} \times 15 \mathrm{~mm} \times 1 \mathrm{~mm})$ were twice sonicated for 10 min consecutively in acetone, isopropyl alcohol and distilled de-ionised water. The abraded coupons were then dried thoroughly in a convection oven at $70{ }^{\circ} \mathrm{C}$ for $12 \mathrm{~h}$. The surface of the silicon coupons was then coated with a polycrystalline titanium interlayer in order to provide a reproducible substrate surface.

\subsection{Sputtering procedure}

RF magnetron sputtering was performed using a cluster of three high vacuum Torus $3 \mathrm{M}$ sputtering sources in a custom designed system (Kurt J. Lesker Ltd., USA) each operating with a $13.56 \mathrm{MHz} \mathrm{RF}$ generator and an impedance matching network (Huettinger, GmbH, Germany). The operational parameters for the creation of the titanium interlayer on the silicon substrates and the different $\mathrm{Ca}-\mathrm{P}$ coatings deposited thereon are detailed in Table $2[6,15,22]$. After sputter deposition, the Ca-P coatings were thermally annealed. The samples were subjected to a ramp rate of $5{ }^{\circ} \mathrm{C} / \mathrm{min}$ to $500{ }^{\circ} \mathrm{C}$ (from room temperature) with a soak time of $2 \mathrm{~h}$ and a ramp rate of $5{ }^{\circ} \mathrm{C} / \mathrm{min}$ back down to room temperature.

\subsection{Characterisation of the $\mathrm{Ca}-\mathrm{P}$ coatings}

FTIR spectroscopy of the samples was carried out using a BIORAD FTS 3000MX Excalibur series instrument with a PIKE diffuse reflectance infrared fourier transform spectroscopy (DRIFTS) accessory [6, 15, 22]. Curve fitting of the FTIR spectra was performed with Origin software (version 8.0). Spectra were baseline corrected and fitted using a Gaussian-Lorenztian function. XRD of the samples was carried using a Bruker D8 Discover Diffractometer fitted with a Gobel Mirror. A $\mathrm{Cu} \mathrm{K} \alpha$ X-ray radiation $(\lambda=1.540 \AA)$ source was employed. For the grazing incidence angle XRD studies of the $\mathrm{Ca}-\mathrm{P}$ coatings on the titanium coated silicon substrates the tube angle was set to 
Table 2 Operational parameters employed during sputter deposition

\begin{tabular}{llll}
\hline Parameter & Titanium interlayer & HA coating & TCP coating \\
\hline Base pressure $(\mathrm{Pa})$ & 0.00006 & 0.00007 & 0.00007 \\
Working gas & Argon $(99.999 \%)$ & Argon $(99.999 \%)$ & Argon $(99.999 \%)$ \\
Power $(\mathrm{W})$ & 200 & 150 & 150 \\
Power density $\left(\mathrm{W} / \mathrm{cm}^{2}\right)$ & 4.4 & 3.3 & 3.3 \\
Chamber pressure $(\mathrm{Pa})$ & 2 & 2 & 2 \\
Gas flow rate $(\mathrm{Sccm})$ & $18-22$ & $18-20$ & $18-20$ \\
Throw distance $(\mathrm{mm})$ & 100 & 100 & 100 \\
Deposition time $(\mathrm{h})$ & 1 & 10 & 10 \\
Coating thickness $(\mathrm{nm})$ & 750 & 288 & 295 \\
\hline
\end{tabular}

$0.75^{\circ}[6,15,22]$. XPS of the samples were carried out using a Kratos Axis Ultra DLD spectrometer. Spectra were recorded by employing monochromated $\mathrm{Al} \mathrm{K} \alpha \mathrm{X}$-rays $[\mathrm{h} v=1,486.6$ electron volts $(\mathrm{eV})]$. Sample charging effects on the measured BE positions were corrected by setting the lowest $\mathrm{BE}$ component of the $\mathrm{C} 1 \mathrm{~s}$ spectral envelope to $285.0 \mathrm{eV}$, i.e. the value generally accepted for adventitious carbon surface contamination. Photoelectron spectra were further processed by subtracting a linear background and using the peak area for the most intense spectral line of each of the detected elemental species to determine the $\%$ atomic concentration. Three areas were analysed for each sample $[6,15,22]$. The surface topography of the samples was evaluated using a Digital Instruments Dimension 3,000 scanning probe microscope (SPM). The images were collected and subjected to minimal computational manipulation, allowing only for a tilt removal $[6,15,22]$. The coating thickness of the titanium layers and the $\mathrm{Ca}-\mathrm{P}$ coatings were determined using a Dektak 8 stylus profilometer (Veeco Instruments Inc., USA). Measurements were taken across 10 step height positions on each sample created by masking the substrates with aluminium foil prior to deposition in the sputtering system $[6,15,22]$.

\subsection{In vitro testing of the $\mathrm{Ca}-\mathrm{P}$ coatings}

\subsubsection{Cell culture}

The MG-63 cells which were used in this study are an immortalised cell line derived from the osteosarcoma of a 14 year old male (American Type Culture Collection, Rockville, MD, USA). Cells were cultured in minimum essential medium (MEM) supplemented with $10 \%$ foetal calf serum and antibiotic/antimycotic (penicillin G sodium $100 \mathrm{U} / \mathrm{ml}$, streptomycin $100 \mu \mathrm{g} / \mathrm{ml}$, amphotericin B $0.25 \mu \mathrm{g} / \mathrm{ml}$, (PAA Laboratories $\mathrm{GmbH}$, Austria) in $75 \mathrm{~cm}^{3}$ Nunc tissue culture flasks. Cells were maintained in a humidified atmosphere with $5 \% \mathrm{CO}_{2}$ at $37{ }^{\circ} \mathrm{C}$ and were sub-cultured several times at the point of confluence using $0.25 \%$ Trypsin ethylenediaminetetraacetic acid (EDTA).

\subsection{Cell attachment}

The nature of the MG-63 cell attachment to the various sample types was determined using the crystal violet staining assay of cells in culture. Cells were seeded onto the samples at a concentration of $1 \times 10^{5}$ cells $/ \mathrm{cm}^{2}$ and allowed to adhere during incubation at $37{ }^{\circ} \mathrm{C}$ in $5 \% \mathrm{CO}_{2}$ for $2 \mathrm{~h}$. Samples were then washed in phosphate buffered saline (PBS) to remove non-adherent cells and then fixed and permeabilised in ice-cold methanol for $20 \mathrm{~min}$. A further wash with PBS 1 was performed for $20 \mathrm{~min}$ and adherent cells were stained with $0.5 \%$ crystal violet solution (Sigma-Aldrich, UK) containing $20 \%$ methanol for $30 \mathrm{~min}$. The cells were subsequently de-stained by three consecutive light washes with DI water, followed by elution of the residual crystal violet with $10 \%$ acetic acid for $30 \mathrm{~min}$ under gentle agitation. The absorbance, measured as optical density (OD), of the eluted solutions was measured in an ELISA plate reader (Tecan Sunrise, Tecan, Austria) at a wavelength of $570 \mathrm{~nm}$ with a background absorbance value measured at $650 \mathrm{~nm}$. The OD values obtained correlate directly with cell number and provided a standardisation of cell numbers between experimental wells, as well as comparing values between sample types.

\subsection{Cell viability}

The proliferation of osteoblastic cells on sputter deposited surfaces in vitro is a good indication of the osteoconductive properties of the surface coating. In that regard, the varied surfaces were comparatively analysed using the MTT (3-(4,5-dimethylthiazol-2-Y1)-2,5-diphenyltetrazolium bromide) cell viability assay. The principle behind this assay relies on the conversion of the yellow MTT reagent to purple, insoluble formazan crystals by mitochondrial dehydrogenases of actively respiring cells. The formazan crystals are then solubilised, with the resulting purple 
solution optically measured using an absorbance plate reader. The increase in OD is proportional to the number of metabolically active cells. Cells were seeded onto the samples at a concentration of $1 \times 10^{5}$ cells $/ \mathrm{cm}^{2}$ and cultured on the samples over a period of 7 days, as described previously. Cell viability was determined using a commercial MTT assay (MTT assay kit, Sigma-Aldrich, UK). The MTT assay reagent was prepared as a $5 \mathrm{mg} / \mathrm{ml}$ stock solution in PBS, sterilised by Millipore filtration, and stored under complete darkness. At each sampling timepoint, an aliquot of the MTT stock solution (10\% of total volume) was added to each well of a six well plate containing the samples. After $3 \mathrm{~h}$ incubation at $37^{\circ} \mathrm{C}$ in $5 \%$ $\mathrm{CO}_{2}, 200 \mu \mathrm{l}$ of MTT solvent $(4 \mathrm{mM} \mathrm{HCl}, 0.1 \% \mathrm{NP}-40$ in isopropanol) (Sigma-Aldrich, UK) was added to dissolve the formazan crystals. The solution was gently agitated for $15 \mathrm{~min}$ on a shaker plate to ensure complete dissolution of the formazan crystals. The OD of the resultant formazan solutions was read by an absorbance plate reader (Tecan Sunrise, Tecan, Austria) at $570 \mathrm{~nm}$, with the background absorbance value measured at $650 \mathrm{~nm}$. The absorbance values recorded were determined to be proportional to the number of cells attached to the membrane surface in each case.

\subsection{Cell morphological analysis}

The MG-63 cells were seeded onto each of the sputter deposited sample substrates at a cell density of $5 \times 10^{5}$ cells $/ \mathrm{cm}^{2}$ in 6-well plates and were incubated for 30 , $60 \mathrm{~min}, 4$ and $24 \mathrm{~h}$. After cell culture, the samples were gently rinsed with PBS to remove any unattached cells and fixed in a modified Karnovsky's fixative (2\% paraformaldehyde $/ 2 \%$ glutaraldehyde in PBS) for $1 \mathrm{~h}$. The samples were then rinsed again in PBS and post-fixed in $1 \%$ osmium tetroxide. A further rinse cycle with PBS was repeated three times before the specimens were dehydrated in an alcohol series $(20,30,50,70,80,90,95 \%$ ethanol for $15 \mathrm{~min}$ each, and then three times in $100 \%$ ethanol for $15 \mathrm{~min}$ ). After post fixation, the samples were chemically dried in ethanol:hexamethyldisilizane (HMDS) in a 1:1 ratio for $30 \mathrm{~min}$, and finally $100 \%$ HMDS for $1 \mathrm{~h}$. Samples were then left to air dry in a laminar flow extraction hood overnight.

Prior to SEM analysis, the insulating nature of the samples surfaces required thin sputter coated, conductive layer in order to reduce surface charging effects. This was achieved by using a Emitech K500X SEM preparation sputter system. SEM was then able to image the substrate topography of the samples and examine the subsequent cell morphology. Images which illustrate the observed biological response to the varied $\mathrm{Ca}-\mathrm{P}$ surfaces were acquired using the Hitachi S-3,200 N variable pressure SEM.
Acquisition of appropriate quality images of the attached and fixed cells on the Ca-P coatings was achieved with an accelerating voltage of $5 \mathrm{kV}$. A working distance of $16 \mathrm{~mm}$ and a chamber pressure of $\sim 100 \mathrm{~Pa}$ were maintained during analysis.

\subsection{Vinculin focal adhesion labelling using immunocytochemistry}

The nature of the physical contact between a cell and a given surface are mediated by focal adhesions. These focal adhesion points result from a condensation of several cytoskeletal proteins on the exterior cellular membrane and maintain a secure attachment of the cell to the surface. As previously mentioned, the appropriate adherence of a cell the material surface is a fundamental requirement for normal cell function. Therefore, the evaluation of focal adhesion contacts is an effective approach to determine the potential functionality of a surface in terms of expressing a desirable cell-surface response. Vinculin has been demonstrated as one of the main constituent proteins within such focal adhesion contacts of osteoblastic cells. In this regard, the immunofluorescent staining of this protein can be used as a clear route to determine the degree of effective cell attachment on a surface.

The MG-63 cells were cultured on the varied surfaces as detailed previously. At $60 \mathrm{~min}$ and $24 \mathrm{~h}$ of cell culturing, the media in the sample well was removed and the cells were rinsed twice in PBS. Adhered cells were then fixed to the surface in $4 \%$ paraformaldehyde in $0.1 \mathrm{M}$ phosphate buffer $(4 \mathrm{~g}$ in $100 \mathrm{ml})$ for $20 \mathrm{~min}$ at room temperature. A further wash in PBS was conducted before a 15 min period of incubation in $1 \%$ bovine serum albumin (BSA: $1 \mathrm{~g}$ in $100 \mathrm{ml}$ of PBS). This blocks all binding proteins and subsequently increases the specificity of vinculin antibody binding. Vinculin primary antibody raised in mouse (Sigma, UK) was diluted in $1 \%$ BSA, (dilution $0.15 \%$ respectively) with $200 \mu \mathrm{l}$ added to each sample for $1 \mathrm{~h}$ at room temperature to allow binding of the vinculin protein present. Finally all samples were washed three times in PBS before the fluorescent secondary antibody anti-mouse raised in goat (Sigma, UK) was added in the same concentration and allowed to take effect for $1 \mathrm{~h}$ at room temperature. In addition, to allow the fluorescent visualisation of the cell nuclei, the cells which were attached to the sample surface were counterstained with $50 \mu \mathrm{g}$ per $\mathrm{ml}$ DAPI dihydrochloride fluorescent dye (Invitrogen, UK), for 2 min. Finally, a drop of Vectashield mounting medium (Vector Laboratories, UK) was added to each sample with a glass coverslide positioned on top of each surface. The edges of the samples were then sealed with a clear nail varnish to prevent samples from drying out. Cell morphology and fluorescence from sites of the fixed cells were 
imaged by a Zeiss LSM5 laser scanning confocal microscope (LSCM). Vinculin focal adhesions were imaged using a $488 \mathrm{~nm}$ laser (activating a green fluorescence) and the DAPI stained nuclei were visualised using a $405 \mathrm{~nm}$ blue diode (activating a blue fluorescence). A $20 \times$ objective lens was used to obtain focused images of the cellsurface interactions across three random regions per sample.

\subsection{Statistical analysis}

All data during cell biology studies were reported as the mean \pm standard deviation values. A one-way analysis of variance (ANOVA) has then been applied to test for statistically significant differences between the sample types with a value of $P<0.05$ considered to be statistically significant. The Bonferroni multiple test comparison test was applied to compare values between successive pairs of sample types with the relevant outputs reported. All statistical analysis was performed using GraphPad Prism Version 3.0 software.

\section{Results and discussion}

\subsection{Characterisation of the Ca-P precursor powders}

The properties of the HA and TCP precursor powder were characterized using FTIR, XRD and XPS to determine the nature of the material prior to its use as a target for the sputter deposition of $\mathrm{Ca}-\mathrm{P}$ coatings. These results have been described previously [24, 25]. From these findings it is clear that purity, crystallinity and stoichiometry of the HA and the TCP starting materials were as expected and confirmed the presence of pure HA and TCP.

\subsection{Characterisation of the $\mathrm{Ca}-\mathrm{P}$ coatings}

The coatings produced from the HA and TCP targets were analysed using FTIR, XRD, XPS, stylus profilometry and AFM to assess the surface properties, both before and after thermal annealing at $500{ }^{\circ} \mathrm{C}$.

\subsection{FTIR}

The properties of the Ca-P coating deposited From the HA targets and TCP targets prior to annealing are largely similar to one another and identical to FTIR results reported previously by the authors (not shown here) [24, 25]. After annealing to $500{ }^{\circ} \mathrm{C}$ the coatings produced from the HA targets were more indicative of HA, as shown in Fig. 1a. Well resolved $\mathrm{P}-\mathrm{O}$ stretching vibrations were

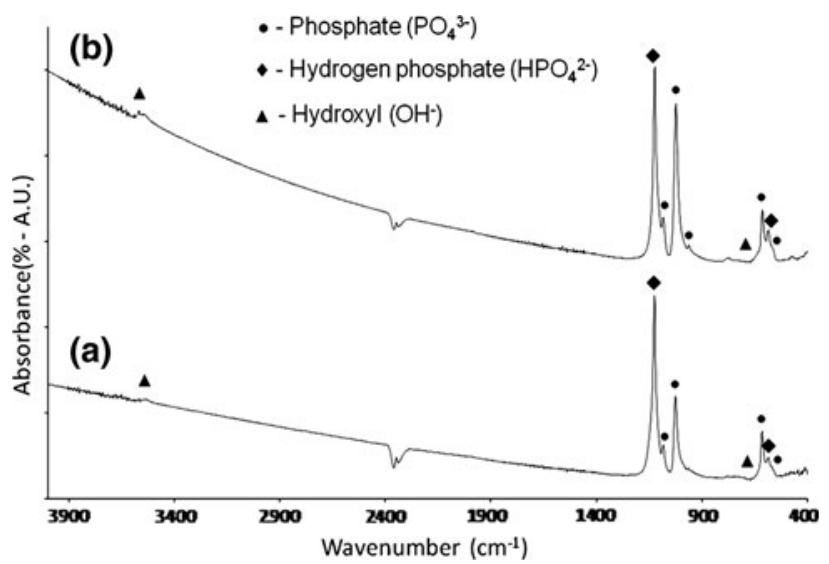

Fig. 1 FTIR Spectra for Ca-P coatings from $a$ HA targets and $b$ TCP targets

observed as expected between 1,100 and $950 \mathrm{~cm}^{-1}$. O-P$O$ bending vibrations are also present between 620 and $560 \mathrm{~cm}^{-1}$. Hydrogen phosphate bands $\left(\mathrm{HPO}_{4}{ }^{2-}\right)$ can also be observed at 1,126, 1,146 and $584 \mathrm{~cm}^{-1}$ [22]. It is worth noting that the $\mathrm{HPO}_{4}{ }^{2-}$ band at $1,148 \mathrm{~cm}^{-1}$ is much more prominent in the TCP derived surface than the HA derived surface, as observed in Fig. 2. Curve-fitting of these results was performed to better understand the functional group bonding in these coatings. Component fitting of both phosphate related IR regions of these spectra $(950-1,200$ and $500-650 \mathrm{~cm}^{-1}$ ) is presented in Fig. $2 \mathrm{a}$, b, with the accompanying tabulated component information detailed in Table 3. A very weak $\mathrm{O}-\mathrm{H}$ librational band is observed around $630 \mathrm{~cm}^{-1}$ as a weak shoulder with a further peak associated with $\mathrm{O}-\mathrm{H}$ groups observed at $3,543 \mathrm{~cm}^{-1}$. This peak may be associated with loosely bound $\mathrm{O}-\mathrm{H}$ groups, or disordered water molecules trapped within the film $[26,27]$. No peaks indicative of $\mathrm{O}-\mathrm{H}$ stretching normally associated with $\mathrm{HA}$ are present at $\sim 3,570 \mathrm{~cm}^{-1}$. The absence of strong $\mathrm{OH}$ functional groups, commonly observed at $\sim 630$ and $3,570 \mathrm{~cm}^{-1}$, indicate a degree of dehydroxylation within the $\mathrm{Ca}-\mathrm{P}$ crystal structure deposited from the HA targets under the conditions employed here. For the coatings deposited from the TCP target (as observed in Figs. 1b, 2c, d; Table 3, the results are largely similar. However, a number of key differences are observed. In particular, the $\mathrm{HPO}_{4}{ }^{2-}$ peak at $1,148 \mathrm{~cm}^{-1}$ is of a greater intensity than that observed for the coatings deposited from the HA targets. In addition, the $\mathrm{P}-\mathrm{O}$ stretch observed at $1,023 \mathrm{~cm}^{-1}$ is also of greater intensity than the corresponding peak in the HA derived coatings. The $\mathrm{O}-\mathrm{H}$ librational band observed at $628 \mathrm{~cm}^{-1}$ also appears as a much more prominent shoulder in the TCP derived surface. However, there is still a distinct lack of an $\mathrm{O}-\mathrm{H}$ stretching peak in the TCP derived coating indicating that this coating 

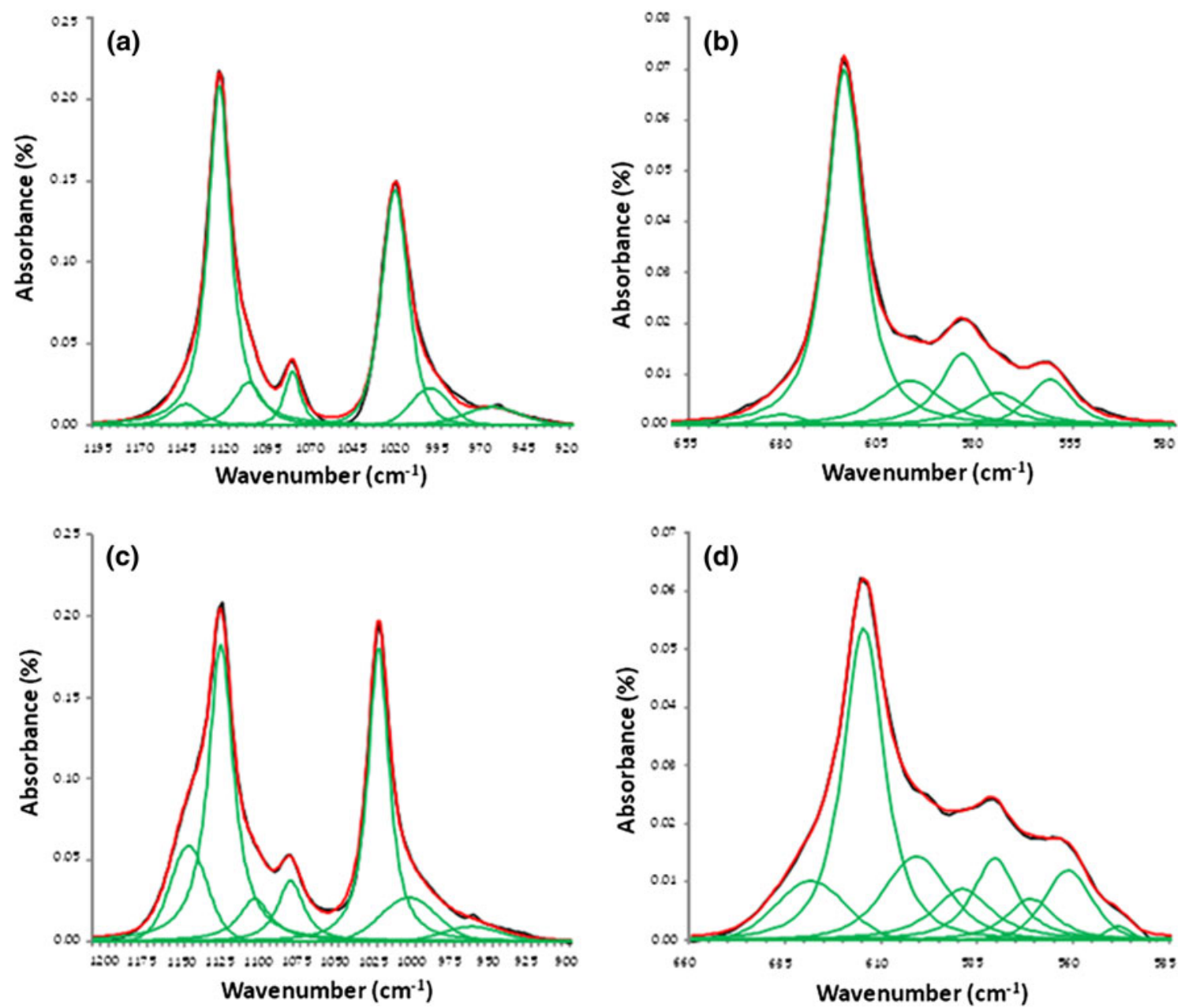

Fig. 2 Component-fitted FTIR spectra for the two main phosphate vibrational regions $\left(\sim 1,200-900\right.$ and $\left.700-550 \mathrm{~cm}^{-1}\right)$ a, b HA targets and c, d TCP targets

is also dehydroxylated, albeit to a lesser degree than the HA derived surface.

\section{$3.4 \mathrm{XRD}$}

The properties of the Ca-P coating deposited From the HA targets and TCP targets prior to annealing are largely similar to one another and identical to XRD results reported previously by the authors (not shown here) [22, $24,25]$. However, upon PDA $\left(500{ }^{\circ} \mathrm{C}\right)$ of the $\mathrm{Ca}-\mathrm{P}$ coating derived from the HA targets as shown in Fig. 3a, peaks that correspond closely to those in the ICDD file \#09-0432 for HA are observed. Furthermore, the intensity of the 002 reflection at $25.9^{\circ} 2 \theta$ is higher than would be expected for a HA coating, which suggests that this coating may have a 002 preferred orientation [22, 24, 25]. Similarly, the coatings derived from the TCP targets, as illustrated in Fig. 3b shows a diffraction pattern that is largely similar to that deposited from the HA targets. The peak positions for the
TCP derived surfaces are identical to that for the HA derived coatings and again correspond closely to those observed in the ICDD file \#09-0432 for HA. However, it should be observed that the 002 reflection in the TCP derived coating has a higher intensity when compared to the same peak in the HA diffraction pattern and again indicates a more prominent 002 preferred orientation for the TCP derived coatings. In the case of both the HA and TCP derived coatings, no significant amorphous background hump was observed. In addition to this no other $\mathrm{Ca}-\mathrm{P}$ phases were detected in the XRD pattern for either PDA annealed coating. Peaks indicative of the underlying titanium interlayer are highlighted in both diffraction patterns shown in Fig. 3.

\subsection{XPS}

The XPS survey and high resolution scans for the AD Ca-P coatings deposited from the HA and TCP targets shows 
peaks corresponding closely to those reported for HA in the literature (not shown here) [22, 24, 25]. The $\mathrm{Ca} / \mathrm{P}$ ratios for the as-deposited HA and TCP derived coatings was $1.33 \pm 0.01$ and $1.24 \pm 0.02$, respectively, as reported in Table 4 . These values are lower than those expected for stoichiometric HA (1.67) and TCP (1.5), respectively. The

Table 3 FTIR bands observed for the Ca-P coatings annealed to $500{ }^{\circ} \mathrm{C}$

\begin{tabular}{lrc}
\hline & TCP $\left(\mathrm{cm}^{-1}\right)$ & HA $\left(\mathrm{cm}^{-1}\right)$ \\
\hline Phosphate & & \\
Asymmetric stretching $\left(V_{3}\right)$ & 1,004 & 1,002 \\
& 1,024 & 1,023 \\
& 1,081 & 1,083 \\
& 1,104 & 1,109 \\
Symmetric Stretching $\left(V_{1}\right)$ & 963 & 966 \\
Asymmetric Bending $\left(V_{4}\right)$ & 548 & - \\
& 561 & 561 \\
& 571 & 574 \\
& 601 & 597 \\
Symmetric Bending $\left(V_{2}\right)$ & 615 & 615 \\
Hydrogenated Phosphate & - & - \\
Asymmetric Stretching & 1,126 & 1,126 \\
Bending & 1,148 & 1,146 \\
Hydroxyl & 581 & 584 \\
Stretching & 589 & - \\
Libration & & 3,543 \\
\hline
\end{tabular}

corresponding XPS data for the $500{ }^{\circ} \mathrm{C}$ PDA Ca-P coatings indicates similar peaks positions to those reported for the as-deposited surfaces. High resolution XPS scans for the $\mathrm{C} 1 \mathrm{~s}, \mathrm{O} 1 \mathrm{~s}, \mathrm{Ca} 2 \mathrm{p}$ and $\mathrm{P} 2 \mathrm{p}$ regions of the $500{ }^{\circ} \mathrm{C}$ PDA $\mathrm{Ca}-\mathrm{P}$ coating from the HA targets are shown in Fig. $4 \mathrm{a}-\mathrm{d}$. These plots were used to determine the quantitative data given in Table 4. The C1s region, shown in Fig. 4a has been curve fitted with four different components. The dominant peak $(285.0 \mathrm{eV})$ is attributed to hydrocarbon species, i.e. $\mathrm{C}-\mathrm{C}$ and/or $\mathrm{C}-\mathrm{H}$, present as a result of adventitious carbon contamination [28-30]. The other peaks at 286.8 and $288.5 \mathrm{eV}$ are typical of $\mathrm{C}-\mathrm{O}$ bonding and $\mathrm{C}=\mathrm{O}$ bonding, respectively [28-30]. The peak at $289.6 \mathrm{eV}$ is indicative of a carbonate $\left(\mathrm{CO}_{3}{ }^{2-}\right)$ species [28-30]. The corresponding O $1 \mathrm{~s}$ peak shown in Fig. 4b can be fitted with two separate peaks. The most intense component at $531.5 \mathrm{eV}$ corresponds to an O-P bonded species and the second peak at $532.9 \mathrm{eV}$ can be attributed to oxygen bonded to carbon and/or $\mathrm{HPO}_{4}{ }^{2-}$ species [22] The $\mathrm{Ca} 2 \mathrm{p}$ region for this as-deposited coating, shown in Fig. $4 c$ exhibits a well-resolved doublet with a $\mathrm{Ca} 2 \mathrm{p}_{3 / 2}$ component at $347.6 \mathrm{eV}$ and a $\mathrm{Ca} 2 \mathrm{p}_{1 / 2}$ component at $351.1 \mathrm{eV}[22,28-30]$. The $\mathrm{Ca} 2 \mathrm{p}_{1 / 2}$ and $\mathrm{Ca} 2 \mathrm{p}_{3 / 2}$ bands are separated by $\sim 3.5 \mathrm{eV}$ and have the correct relative intensity ratio of $3: 1$. The fitted P2p envelope shown in Fig. $4 \mathrm{~d}$ indicates the presence of a single component with a B.E. position of $133.9 \mathrm{eV}$, which corresponds to the $\mathrm{P}-\mathrm{O}$ bonding in a $\mathrm{Ca}-\mathrm{P}$ material $[22,28-30]$. The $\mathrm{Ca} / \mathrm{P}$ ratio of the as-deposited $\mathrm{Ca} / \mathrm{P}$ coatings was $1.82 \pm 0.06$ as reported in Table 4, a value slightly higher than expected for stoichiometric HA (1.67). Similar peak positions are also observed for the $500{ }^{\circ} \mathrm{C}$ PDA Ca-P coating derived from
Fig. 3 XRD patterns for $\mathrm{Ca}-\mathrm{P}$ coatings from $a$ HA targets and $b$ TCP targets

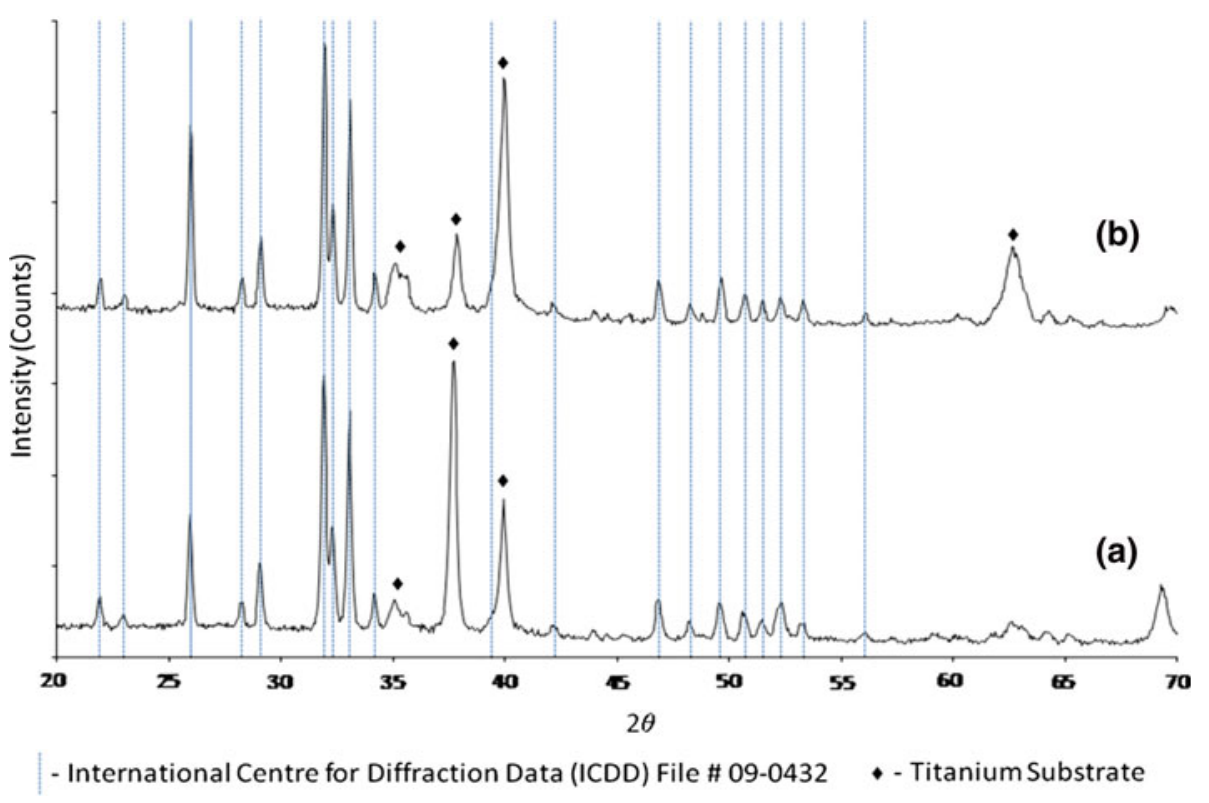


Table 4 Comparative $\mathrm{Ca} / \mathrm{P}$ ratios determined using XPS analysis

\begin{tabular}{llll}
\hline Target material & Powder & AD coating & PDA coating \\
\hline 3 TCP & $1.49 \pm 0.03$ & $1.24 \pm 0.02$ & $1.71 \pm 0.01$ \\
$3 \mathrm{HA}$ & $1.64 \pm 0.04$ & $1.33 \pm 0.01$ & $1.82 \pm 0.06$ \\
\hline
\end{tabular}

the TCP targets as shown in Fig. 4e-h. However, the Ca/P ratio of the TCP derived coatings was seen to increase to $1.71 \pm 0.01$ after PDA to $500^{\circ}$, as shown in Table 4 . This value is close to that expected for stoichiometric HA, and is much lower than that obtained for the HA derived coatings.
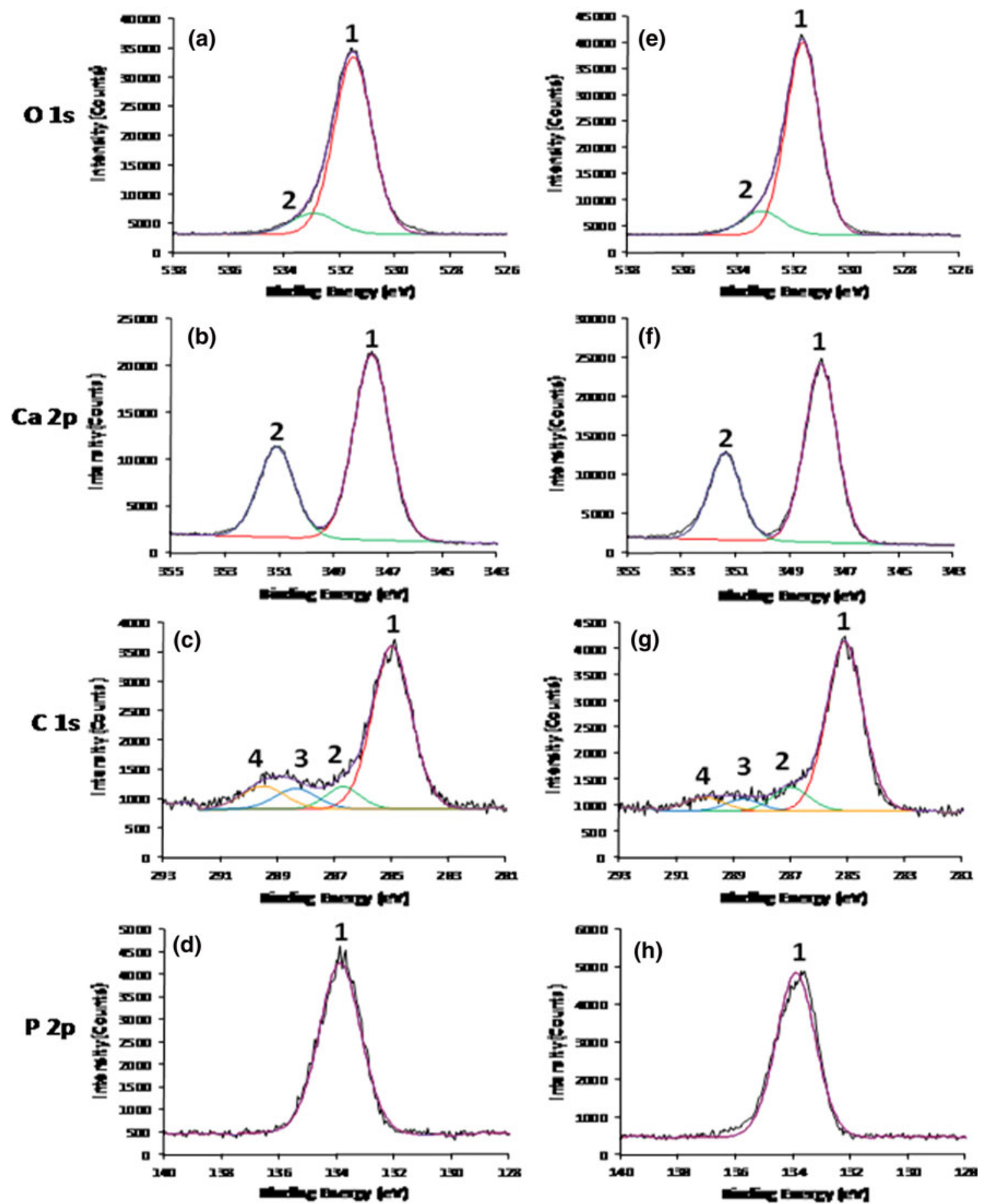

Fig. 4 Comparison of high resolution XPS region spectra obtained from the Ca-P surfaces for biological assessment deposited from HA (a-d) and TCP $(\mathbf{e}-\mathbf{h})$ targets 


\subsection{AFM}

AFM analysis of the silicon substrate (not shown here) indicated a planar and featureless surface with a low surface roughness value $\left(R_{a}\right)$ of $1.9 \mathrm{~nm} \pm 0.4 \mathrm{~nm}$ $(5 \mu \mathrm{m} \times 5 \mu \mathrm{m}$ analysis areas of the samples). After deposition of the titanium interlayer the surface roughness $\left(\mathrm{R}_{\mathrm{a}}\right)$ of the titanium coated silicon (not shown here) was seen to increase significantly $24.0 \pm 4.0 \mathrm{~nm}$ with the presence of titanium microcrystallites of between 100 and $300 \mathrm{~nm}$ in diameter. These microcrystallites form a uniform layer across the surface of the substrate and have dimensions similar to those observed previously on similar planar surfaces [22]. The corresponding AFM results for the as-deposited $\mathrm{Ca}-\mathrm{P}$ coating deposited from the HA targets (not shown here) show a relative tendency for the coatings to mimic the substrate topography of the titanium coated silicon substrates. The surface roughness value $\left(R_{a}\right)$ of the as-deposited HA derived surfaces was $15.2 \pm 1.4 \mathrm{~nm}$, which suggests that there has been some in-filling of the surface of the titanium coated substrate by the $\mathrm{Ca}-\mathrm{P}$ coating (derived from HA targets) due to a slight decrease in the observed surface roughness values. This phenomenon is typical of previous studies utilising similar RF magnetron sputter deposited calcium phosphate coatings $[6,11,13,22,24,25]$. The results observed from the TCP derived as-deposited surfaces were identical to those observed for the HA derived surfaces. However, after PDA to $500{ }^{\circ} \mathrm{C}$, the surfaces derived from the HA coatings (as shown in Fig. 5a exhibited a lower surface roughness $\left(R_{a}\right)$ than the corresponding as-deposited surface at $4.7 \pm 0.8 \mathrm{~nm}$. However, the surface topography appears to be more homogeneous in nature with $\mathrm{Ca}-\mathrm{P}$
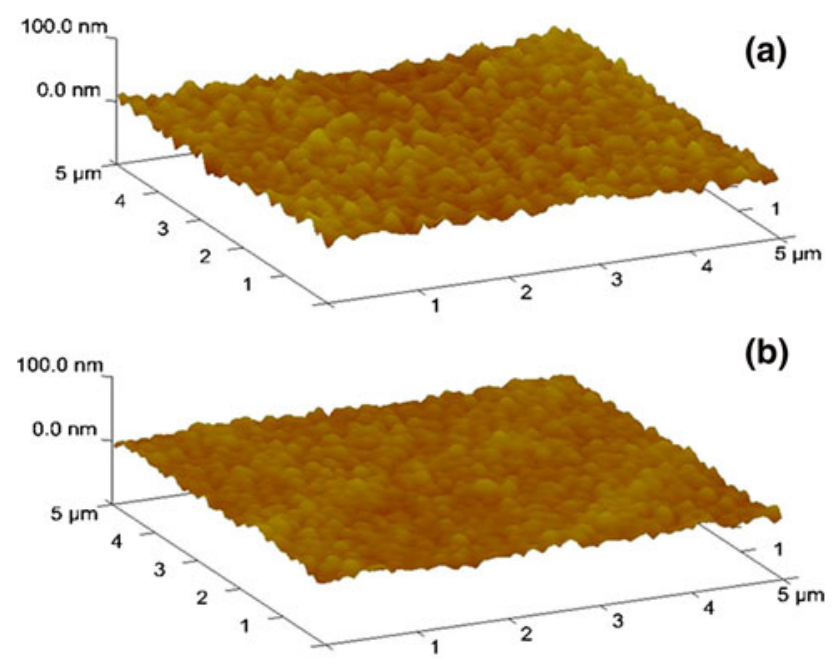

Fig. 5 AFM images demonstrating the surface topography of the $\mathrm{Ca}-$ $\mathrm{P}$ thin films before biological assessment from a HA targets and b TCP targets microcrystallites consistently measuring around $220 \mathrm{~nm}$ in diameter $(218 \pm 29 \mathrm{~nm})$. The $500{ }^{\circ} \mathrm{C}$ PDA TCP derived samples show no significant differences from the $500{ }^{\circ} \mathrm{C}$ PDA HA derived samples with a surface roughness $\left(\mathrm{R}_{\mathrm{a}}\right)$ value of $5.4 \pm 0.6 \mathrm{~nm}$ and consistent microcrystallite diameters of $210 \pm 27 \mathrm{~nm}$. Additional larger spherical features can also been seen periodically on both of these surfaces measuring up to $1 \mu \mathrm{m}$ in diameter. Based on this information the surface topography of the $500{ }^{\circ} \mathrm{C}$ PDA Ca$\mathrm{P}$ samples are identical in nature, with the only significant differences found to be related to the surface $\mathrm{Ca} / \mathrm{P}$ ratios and the degree of preferred 002 orientation.

\subsection{In vitro testing of the $\mathrm{Ca}-\mathrm{P}$ coatings}

Cell adhesion, spreading, viability and proliferation are regarded as the fundamental processes related to assessing initial cell response and subsequently the potential bioactivity of these $\mathrm{Ca}-\mathrm{P}$ surfaces. Cell adhesion is the first step of cell-surface interactions which in part determines the following stages of cell viability, proliferation and possible cell differentiation (although this remains outside the realms of this research). In this regard, the inability to attain suitable cell attachment may result in cell senescence, and as such, cell adhesion is considered a good indicator of appropriate biocompatibility of these $\mathrm{Ca}-\mathrm{P}$ surfaces. As the AD Ca-P surfaces were known to be unstable under physiological conditions they were not tested here as part of this study. Only those surfaces annealed to $500{ }^{\circ} \mathrm{C}$ from the TCP and HA targets were tested in vitro. A titanium coated silicon sample was utilised here as a suitable control.

\subsection{Cell attachment}

The crystal violet assay was utilised to assess cell attachment after $4 \mathrm{~h}$ in culture. After $4 \mathrm{~h}$ of cell culture a similar

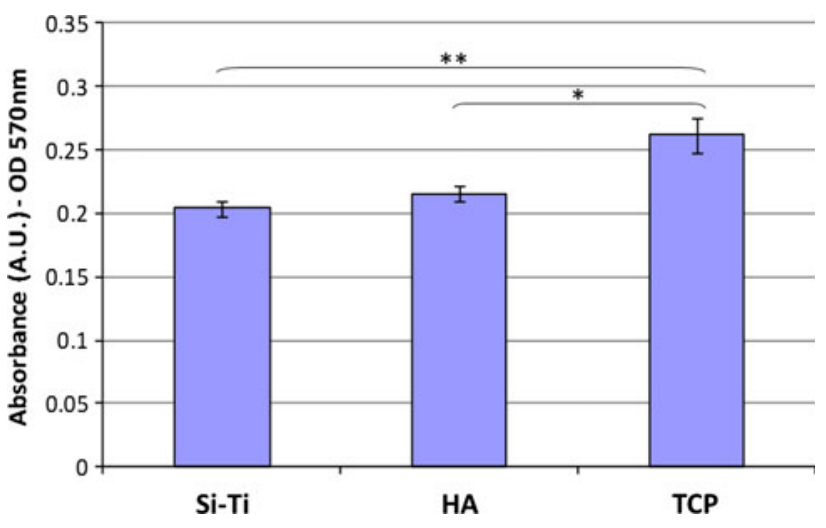

Fig. 6 Results of crystal violet assay for cell attachment between control surface $\mathrm{Si}-\mathrm{Ti}$ and augmented $\mathrm{Ca}-\mathrm{P}$ surfaces $(* P<0.01$, $* * P<0.001)$ 
level of attachment is observed between the control surface (titanium coated silicon $(\mathrm{Si}-\mathrm{Ti}$ ) and the $\mathrm{Ca}-\mathrm{P}$ thin films derived from HA targets, both indicating appropriate surface properties for MG-63 cell attachment. However, a significant difference in the cell number is clearly observed between the TCP derived surfaces and both the $\mathrm{Si}-\mathrm{Ti}$ control and the HA derived coating. Significantly greater cell attachment was also observed on the TCP surfaces in comparison to the control surface $(P<0.001)$ and the HA deposited surface $(P<0.01)$ as shown in Fig. 6 .

\subsection{Cell viability}

Cell viability was determined using a MTT assay after 1, 3 and 7 days in vitro culture. Cell viability was measured as a direct correlation to the OD. The results of the MTT assay can be observed in Fig. 7. It is clearly evident from these results that cells are viable on all surfaces, with a
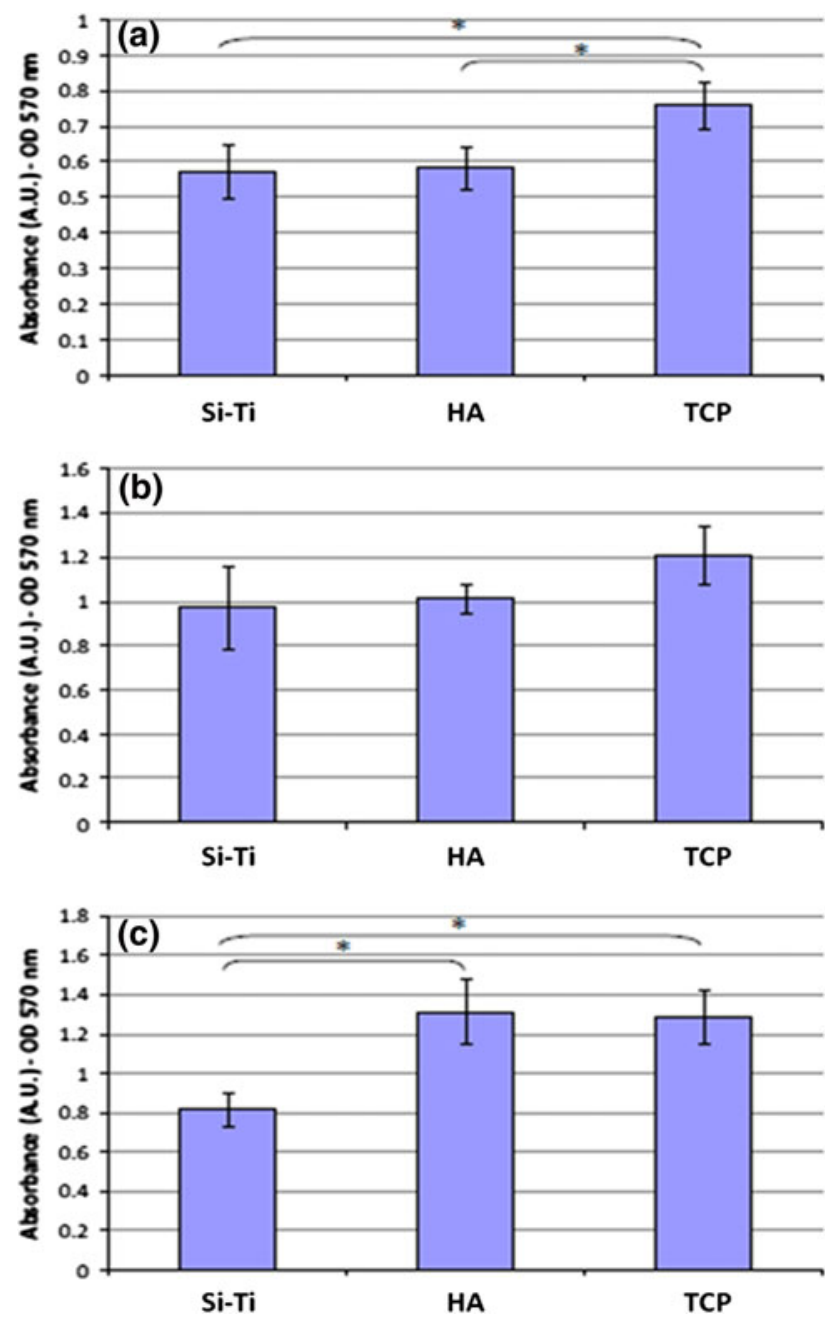

Fig. 7 Results from MTT cell viability assay of osteoblast-like cells on the control $\mathrm{Si}-\mathrm{Ti}$ surface and the augmented $\mathrm{Ca}-\mathrm{P}$ surfaces at a 1 day, b 3 days and $\mathbf{c} 7$ days $(* P<0.05)$ statistically significant difference observed between the optical densities measured at different time points for each of the respective surfaces. In terms of the comparison of cell viability between the treated substrates, it was clear that after 1 day in vitro, an increase in the number of metabolically active cells was found on the thin films deposited from TCP targets. The increase in OD observed in the TCP derived samples was shown to be statistically significant with respect to both the $\mathrm{Si}-\mathrm{Ti}$ control surface and coating deposited from HA targets $(P<0.05)$. No statistical difference could be established between the control surface and the HA target derived $\mathrm{Ca}-\mathrm{P}$ surface. At the 3 day sampling point, although the greatest increase in cell proliferation is observed on the TCP deposited thin film. There is no statistically significant difference between this surface and the other two samples. However, after 7 days of in vitro culture, the enhanced surface functionality of the $\mathrm{Ca}-\mathrm{P}$ surfaces in relation to the control surface is clearly evident. Both these surfaces demonstrate a considerably higher rate of cell proliferation compared to the $\mathrm{Si}-\mathrm{Ti}$ control surface $(P<0.05)$. The measured cell numbers on the $\mathrm{Ca}-\mathrm{P}$ surfaces, show no discernible difference at this time point between the different $\mathrm{Ca}-\mathrm{P}$ surfaces. This indicates that after 7 days of cell culture, there is no difference in the number of viable MG-63 cells on either $\mathrm{Ca}-\mathrm{P}$ surface. It is possible that cell proliferation has ceased due to the limitation imposed by a confluent cell layer. However, it was noted that at the earlier time points a higher degree of cell proliferation exists on the samples with the lower $\mathrm{Ca} / \mathrm{P}$ ratio surface (TCP targets), therefore indicating confluence may be reached during a shorter time period of in vitro culture.

\subsection{Cell morphology (SEM analysis)}

The morphological evaluation of the adhered cells on a surface provides a level of complimentary qualitative analysis to the data obtained from the biological assays. The cell shape (morphology) is highly indicative of the cell behaviour in relation to both adhesion and viability, as it should be observed that a cell which has a positive interaction with the ideal surface properties will show signs of cell spreading on the surface. This process should occur rapidly when the cell contacts a surface, as demonstrated in Fig. 8 for the HA derived surface, which shows the morphological behaviour of the cells at 30, 60 min and $4 \mathrm{~h}$ of cell culture. It is observed that after $30 \mathrm{~min}$, cell spreading is already underway on all surfaces. However, the majority of the cells viewed at this time point demonstrate rounded cell morphology, indicating that the cells have not fully interacted with the surfaces and full cell attachment has not occurred. Filopodia are seen to be protruding from all the cells on each surface type (Fig. $8 \mathrm{a}-\mathrm{c}$ ) at this time-point, 


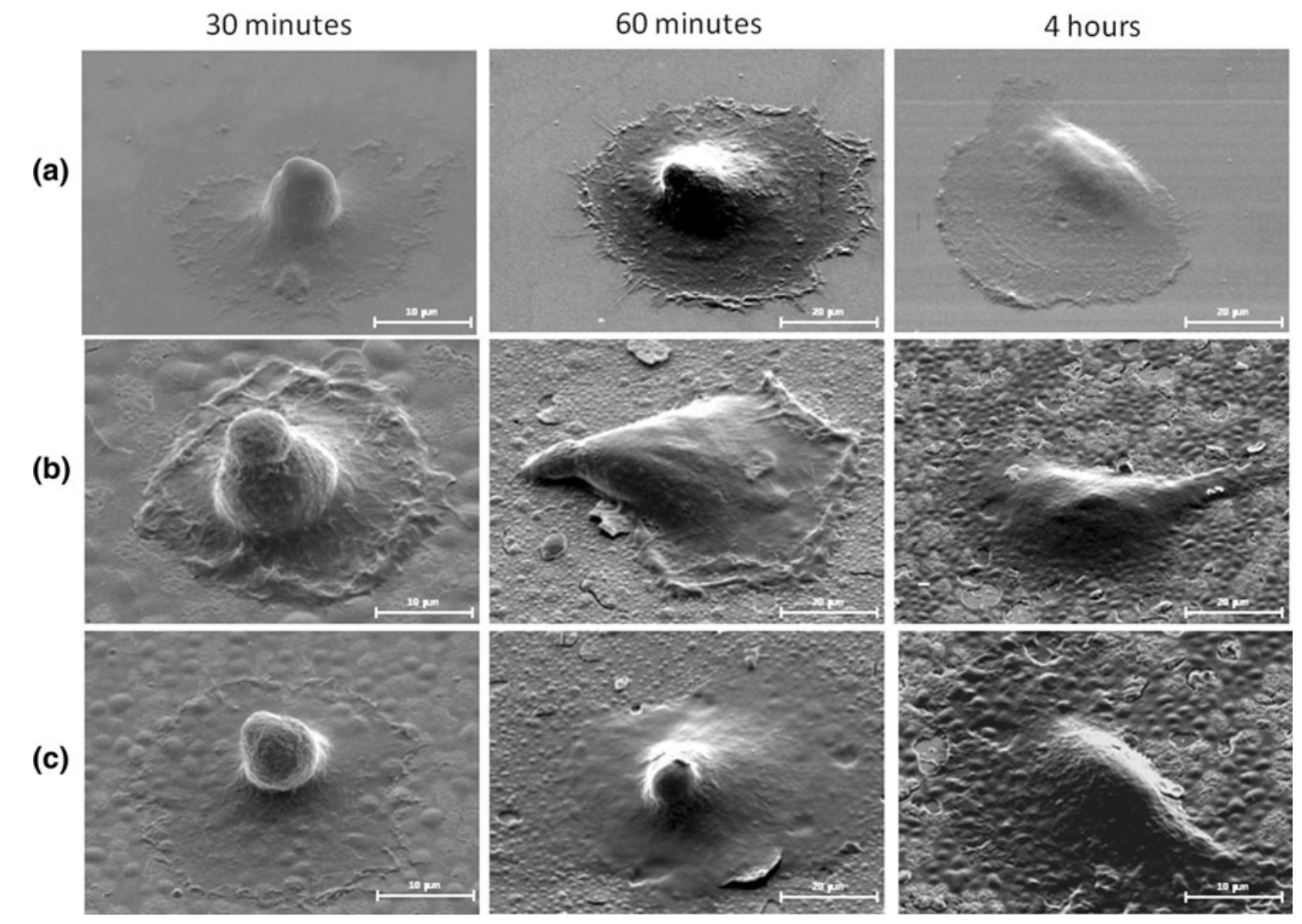

Fig. 8 SEM images showing cell morphology and spreading after 30, $60 \mathrm{~min}$ and $4 \mathrm{~h}$ for the varied surfaces for a Si-Ti, and thermally processed $\mathrm{Ca}-\mathrm{P}$ surfaces $\mathbf{b}$ from $\mathrm{HA}$ and $\mathbf{c}$ from TCP

indicating that the cells have begun to probe the underlying substrate for topographical features to further guide their attachment. The degree of cell spreading observed on both the TCP and HA derived coatings after $60 \mathrm{~min}$ of cell culture is highly comparable to the spreading behaviour observed on the titanium thin film control surface. Indications of surface delamination were also observed during the in vitro study of these Ca-P surfaces, as shown in Fig. 9d. This may indicate (1) areas of the Ca-P film with an irregularly higher surface energy making them more prone to dissolution and so a weakening of the structural integrity, (2) strong adhesive forces generated by cell attachment capable of dislodging surface fragments or (3) issues associated with the cell-surface fixation process. At both the $60 \mathrm{~min}$ and $4 \mathrm{~h}$ stage of cell culture the adhered cells have spread out across the different surfaces with the cells exhibiting a fibroblastic morphology, as can be seen in Fig. 8 [31]. After 1 and $4 \mathrm{~h}$ cell culture in vitro, the SEM analysis suggests the MG-63 cells are well adhered to all the surfaces tested (including the Ti-Si control), indicating that each of these surfaces display appropriate biocompatibility. A further interesting observation here is the fact that the surface morphology of the coatings undergoes a degree of change at these early time points in culture (between 30 and 60 min in particular as shown in Fig. 8). It is noted that after 60 min the surfaces of both $\mathrm{Ca}-\mathrm{P}$ coatings had an increased density of spherulitic features (of diameters of between $200 \mathrm{~nm}$ and $1 \mu \mathrm{m}$ ) when compared to the $30 \mathrm{~min}$ stage. These features are random in their arrangement right across each different coating. After $4 \mathrm{~h}$ the spherulitic features are not observed continuously across the whole surface of the coatings, with some areas exhibiting a degree of porosity and others appearing to delaminate.

After $24 \mathrm{~h}$ of cell culture, there was a general observation that the cells which adhered to the $\mathrm{Si}$-Ti surfaces demonstrated a degree of cell spreading, however a high relative proportion of the cells still presented a rounded morphology, and as such, non-optimised adhesion. The $\mathrm{Ca}-\mathrm{P}$ surfaces were observed to promote a greater number of cells displaying a well spread morphology. SEM images of these surfaces can be observed in Fig. 9a, c. Additionally, from these images the density of attached cells on the surface was established to be higher on the surface with a lower $\mathrm{Ca} / \mathrm{P}$ ratio (from the TCP targets). The images obtained and presented in this figure are representative of the conditions observed across the rest of both of the different $\mathrm{Ca}-\mathrm{P}$ surfaces. Although the nature of SEM images, 
Fig. 9 SEM images

demonstrating the filopodia protruding from the cell membrane and contacting the surface of the $\mathrm{Ca}-\mathrm{P}$ films for the HA derived surface $(\mathbf{a}, \mathbf{b})$ and the TCP derived surface $(\mathbf{c}, \mathbf{d})$
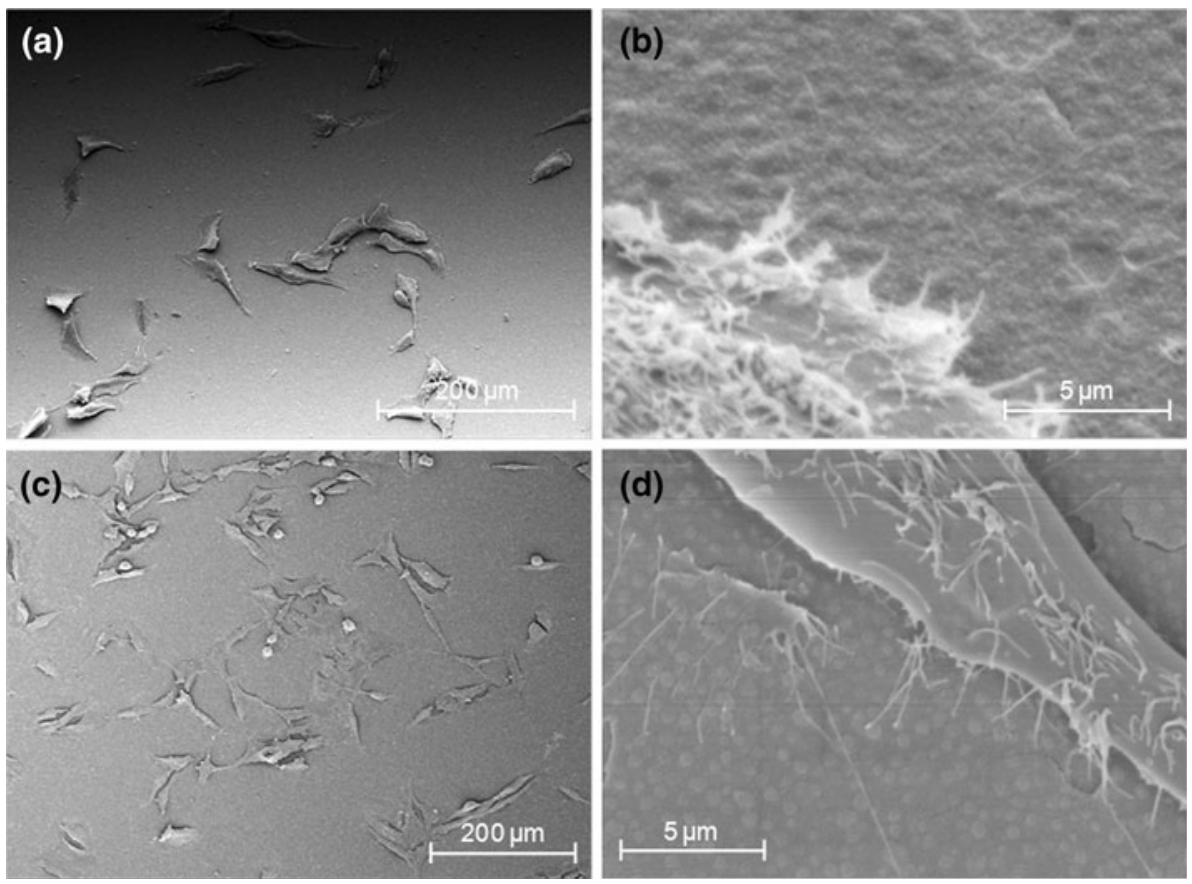

such as those exhibited here, are qualitative, an increase in the number of well adhered and metabolically active cells on the TCP derived surfaces after $24 \mathrm{~h}$ of cell culture does agree with the results observed in both the crystal violet and MTT assays at the same sampling time points.

In the higher magnification SEM images of the cell response to the sputtered $\mathrm{Ca}-\mathrm{P}$ thin films, observed in Fig. 9b, d, filopodia are shown to extend out from the cell membrane in the order of tens of microns. This was observed on both surfaces. However, this phenomenon was more prominent on the TCP derived surface with a lower $\mathrm{Ca} / \mathrm{P}$ ratio $(1.71)$. The cellular interactions with this $\mathrm{Ca}-\mathrm{P}$ surface clearly shows the filopodia of the cell membrane adhering to the surface of the curved topography of the grains present in the coating. This suggests the osteoblastic MG-63 cells are responsive to the topographical features presented by this $\mathrm{Ca}-\mathrm{P}$ thin film, which are largely on the meso- to micro scale ( $>200 \mathrm{~nm}$ in diameter).

\subsection{Immunofluorescent imaging of vinculin focal adhesions}

The immunofluorescent staining of the MG-63 cells on the control and $\mathrm{Ca}-\mathrm{P}$ surfaces revealed varying levels of vinculin adhesions on the peripheries of the cell membranes. After $1 \mathrm{~h}$ of cell culture in vitro, the cells adhered to the various surfaces were exhibiting a rounded morphology. On the control surface ( $\mathrm{Ti}-\mathrm{Si}$ ) vinculin expression demonstrated a homogeneous distribution around the entire boundary of the cell. No clear areas of localisation of this attachment protein were observed during confocal analysis.
In contrast, the $\mathrm{Ca}-\mathrm{P}$ surfaces demonstrated clear areas of localised vinculin focal adhesions. These accumulations of vinculin at basal sites of the cellular membranes can be observed in Fig. 10b, c. On comparison to the SEM analysis of these cells, an even distribution of vinculin at the membrane of more rounded cell morphologies is noted, whereas cells which are demonstrating a well spread morphology exhibit a preferential localisation of vinculin agglomerates at the extremities of the cell periphery. This phenomenon was observed more frequently during the analysis of the surfaces deposited from TCP targets, with the fluorescence from sites of localised vinculin displaying a greater intensity. It should also be highlighted that instances of filopodia expansion across the material surface generally exhibited higher levels of vinculin than the adjacent regions of cell membrane. Filopodia were generally observed to extend further on the lower $\mathrm{Ca} / \mathrm{P}$ ratio surfaces (derived from TCP targets) indicating a greater affinity for secure cell attachment at early stages of cell culture on these surfaces.

At $24 \mathrm{~h}$ of cell culture, the MG-63 cells no longer exhibit the rounded morphology observed at the very early stages of attachment and instead demonstrate extensive cell spreading on all the surfaces. The extension of the cells in one direction, (with a significantly reduced cell aspect ratio), illustrates the evolution of a more fibroblastic morphology of this cell line. This change in cell shape to the well spread form of a more mature cell is suggestive of a strong cell-surface adhesion which may promote subsequent cellular processes. On both the $\mathrm{Si}-\mathrm{Ti}$ control surface and the $\mathrm{Ca}-\mathrm{P}$ surface deposited from HA targets, the 
Fig. 10 LSCM images demonstrating MG-63 cell morphologies stained for vinculin focal adhesions at 1 and $24 \mathrm{~h}$ a $\mathrm{Si}-\mathrm{Ti}$ surface, and thermally processed $\mathrm{Ca}-\mathrm{P}$ surfaces derived from $\mathbf{b}$ HA targets and $\mathbf{c}$ TCP targets
1 hour

(a)

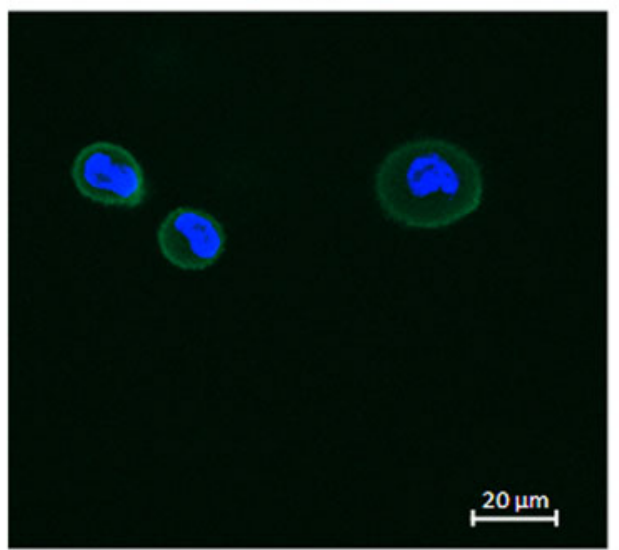

(b)

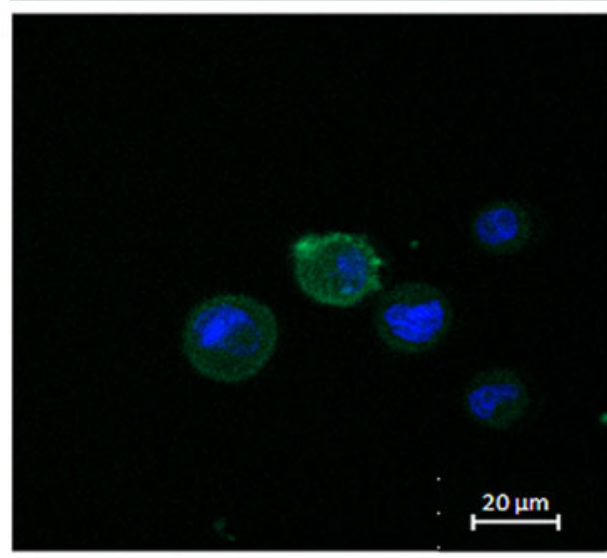

(c)

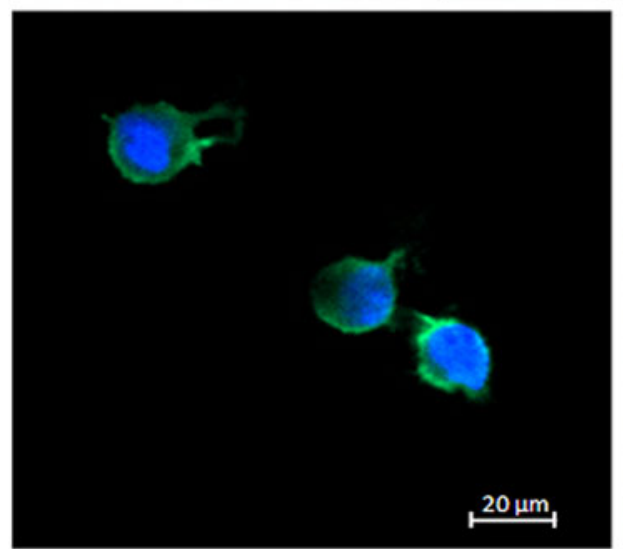

24 hours
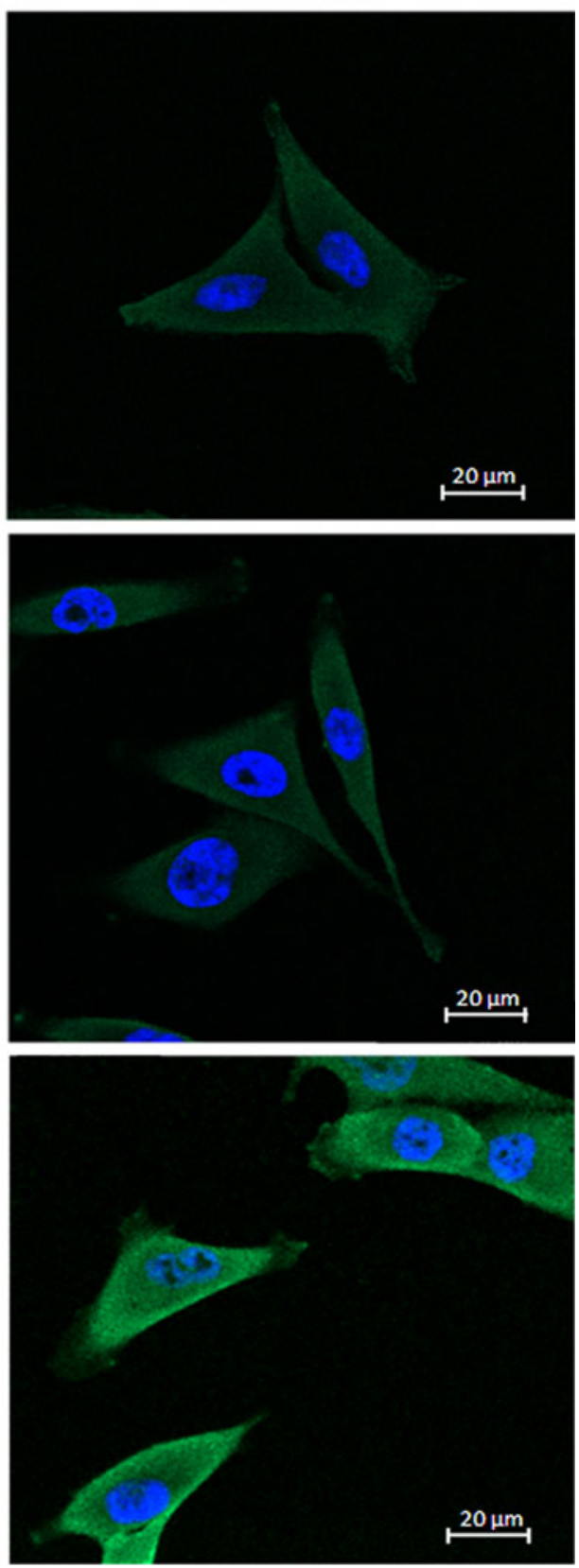

level of vinculin fluorescence demonstrates a homogeneous distribution across the cellular membrane indicating a greater affinity for this type of surface to promote complete cell adherence.

In the case of the Ca-P surface derived from the TCP targets, a more intense fluorescence related to the presence of vinculin was noted, indicating a higher concentration at the edges of the osteoblastic membrane. In addition a number of regions of clear protein localisation were observed. These observations therefore suggest an enhanced level of focal adhesion contacts with the surface. In this regard these lower $\mathrm{Ca}-\mathrm{P}$ ratio surfaces indicate an enhanced functionality with respect to ensuring strong levels of cell attachment. The development of an improved cell adhesion response to these surfaces supports the same pattern observed at $60 \mathrm{~min}$ in the culture environment. The results suggest a greater affinity of these lower $\mathrm{Ca} / \mathrm{P}$ ratio surfaces (derived from $\mathrm{TCP}$ ) to support enhanced cell adhesion.

\section{Discussion}

RF magnetron sputter deposition from two sets of varied $\mathrm{Ca}-\mathrm{P}$ phase targets was utilised to create thin films with 
controlled surface properties. A clear variation in the surface $\mathrm{Ca} / \mathrm{P}$ ratio was evident between these coatings. However, the surface topography of both sets of coatings were largely similar, with only a marginal difference in the size of the average surface features reported from the AFM results. This allowed for the coatings to be tested in vitro, whereby the main variation was down to only the chemistry of the different surfaces, most notably the $\mathrm{Ca} / \mathrm{P}$ ratio.

The surface $\mathrm{Ca} / \mathrm{P}$ ratio of the thin films deposited from three HA targets and three TCP targets were determined to be $1.82 \pm 0.06$ and $1.71 \pm 0.01$, respectively. The $\mathrm{Ca} / \mathrm{P}$ ratio of the coating deposited from TCP targets was therefore closer to stoichiometric HA (1.67). FTIR analysis highlighted the fact that there had been hydrogenation of the phosphate functional groups in both Ca-P films; however, it was more pronounced in the TCP derived films as illustrated in Fig. 2a, c. Conversely, both the $\mathrm{Ca}-\mathrm{P}$ coatings deposited in this way exhibited a strong degree of dehydroxylation, with the HA derived coating showing less hydroxylation in comparison to the TCP derived surfaces. Reduced hydroxylation is suggested to have a significant influence on the atomic ordering of $\mathrm{Ca}-\mathrm{P}$ coatings $[32,33]$ and their subsequent stability in physiological environments [6]. A significant reduction in $\mathrm{OH}^{-}$groups suggests the charge balance necessary within the crystal structure must therefore be provided by other means. HA is understood to undergo carbonate $\left(\mathrm{CO}_{3}{ }^{2-}\right)$ substitution within the crystal lattice at multiples sites. Most notably, A type substitution (for $\mathrm{OH}^{-}$groups), $\mathrm{B}$ type substitutions (for $\mathrm{PO}_{4}{ }^{3-}$ groups), or both (AB) substitution are acknowledged as providing for charge balance in the lattice structure of HA [32, 34]. It is now widely accepted that in natural apatite, $B$ type substitutions dominate [32]. The FTIR results obtained here cannot confirm the presence or absence of $\mathrm{CO}_{3}{ }^{2-}$ groups in the lattice of any of the samples due to the observed specular reflectance in the spectra above $1,200 \mathrm{~cm}^{-1}$, therefore a direct determination of A, B or AB substitution cannot be made here. However, the XPS analyses of the coatings do confirm $\mathrm{CO}_{3}{ }^{2-}$ in these coatings from the presence of significant peaks at around 289-290 eV in the C1s envelope [22, 24, 25]. In consideration of this it appears logical that $\mathrm{CO}_{3}{ }^{2-}$ substitution exists in coatings, and it is this species that acts to balance the charges within both samples deposited here. However, given the FTIR results the role of $\mathrm{HPO}_{4}{ }^{2-}$ substitution within the lattice cannot be discounted. It is important to highlight that $\mathrm{CO}_{3}{ }^{2-}$ was only detected via the XPS analysis, whereas $\mathrm{HPO}_{4}{ }^{2-}$ was detected by both the XPS and FTIR analyses. It was assumed as no other impurities were present as only $\mathrm{CO}_{3}{ }^{2-}$ and $\mathrm{HPO}_{4}{ }^{2-}$ were detected in any of the analyses performed. For example, no evidence for the presence of $\mathrm{CaO}, \mathrm{Ca}(\mathrm{OH})_{2}$ or $\mathrm{CaCO}_{3}$ was found in the XRD, FTIR or XPS analyses. Therefore, both the different $\mathrm{Ca}-\mathrm{P}$ coatings produced here can be said to resemble something close to naturally occurring apatite in bone rather than pure HA in that they contain carbonate, are dehydroxylated and non-stoichiometric [35]. Furthermore, it is assumed that the material deposited here is not a calcium deficient hydroxyapatite (CDHA) material either $\left[\mathrm{Ca}_{10-\mathrm{X}}\left[\left(\mathrm{PO}_{4}\right)_{6-\mathrm{X}}\left(\mathrm{HPO}_{4}\right)_{\mathrm{X}}\right](\mathrm{OH})_{2-\mathrm{X}}\right]$, as this would result in a material that has a $\mathrm{Ca} / \mathrm{P}$ ratio less than 1.67 [32]. Furthermore, the presence of $\mathrm{CO}_{3}{ }^{2-}$ is not provided for in this CDHA system. As mentioned previously, as no $\mathrm{CaO}$, $\mathrm{Ca}(\mathrm{OH})_{2}$ or $\mathrm{CaCO}_{3}$ (or other Ca-P phases) species were detected, these species could not be responsible for the high $\mathrm{Ca} / \mathrm{P}$ ratios in the different coatings deposited here. In this study both of the coatings deposited had $\mathrm{Ca} / \mathrm{P}$ ratios higher than 1.67 (1.71 and 1.82 for the TCP and HA derived coatings, respectively). The possible stoichiometry of the TCP and HA derived coatings here may be described by the formula $\mathrm{Ca}_{10-\mathrm{X}}\left(\mathrm{PO}_{4}\right)_{6-\mathrm{X}}\left(\mathrm{CO}_{3}\right)_{\mathrm{X}}(\mathrm{OH})_{2-\mathrm{X}}(\mathrm{Ca} / \mathrm{P}$ ratio $\geq 1.67)$ [32]. However, this would discount the presence of $\mathrm{HPO}_{4}{ }^{2-}$ species in the lattice. Therefore, it is suggested that the possible formula for the coatings produced here could be described by $\left.\mathrm{Ca}_{10-\mathrm{X}-\mathrm{Y} / 2}\left[\mathrm{HPO}_{4}\right)\left(\mathrm{PO}_{4}\right)\right]_{6-\mathrm{X}-\mathrm{Y}}\left(\mathrm{CO}_{3}\right)_{\mathrm{Y}}(\mathrm{OH})_{2-\mathrm{X}}$ [36]. The presence of both $\left[\mathrm{Ca}_{10-\mathrm{X}}\left[\left(\mathrm{PO}_{4}\right)_{6-\mathrm{X}}\left(\mathrm{HPO}_{4}\right)_{\mathrm{X}}\right](\mathrm{OH})_{2-\mathrm{X}}\right]$ and $\mathrm{Ca}_{10-\mathrm{X}}\left(\mathrm{PO}_{4}\right)_{6-\mathrm{X}}\left(\mathrm{CO}_{3}\right)_{\mathrm{X}}(\mathrm{OH})_{2-\mathrm{X}}$ species cannot be discounted as well, along with the possibility of labile $\mathrm{CO}_{3}{ }^{2-}$ and $\mathrm{HPO}_{4}{ }^{2-}$ in the lattice [37]. Given the range of possibilities here and the results obtained it is difficult to determine the exact formulae of the coatings produced. Despite this, the XRD and FTIR results do confirm the presence of dehydroxylated HA in the coatings and the FTIR and XPS results confirm the presence of both $\mathrm{CO}_{3}{ }^{2-}$ and $\mathrm{HPO}_{4}{ }^{2-}$ species. The $\mathrm{CO}_{3}{ }^{2-}$ and $\mathrm{HPO}_{4}{ }^{2-}$ appear either as substitutional ions in the lattice of the coatings obtained (or as labile materials), or both. Further to this, the TCP derived coating has a slightly higher level of $\mathrm{CO}_{3}{ }^{2-}$ and $\mathrm{HPO}_{4}{ }^{2-}$ as can be seen in the FTIR and XPS results. In addition, the surface $\mathrm{Ca} / \mathrm{P}$ ratio of the TCP deposited films demonstrated a greater affinity with the values associated with natural apatite [34]. These are small, but perhaps significant differences that may influence the stability of the coatings in a physiological environment and its biological performance, in vitro.

Introduction of these $\mathrm{Ca}-\mathrm{P}$ films into the in vitro cell culture environment produced a number of interesting results. Both the sputter deposited thin films displayed appropriate cell adhesion and proliferation compared to the titanium control surface. Suitable cell attachment on a surface supports the development of normal cell activity. During the attachment assay it was apparent that the $\mathrm{Ca}-\mathrm{P}$ surface deposited from the TCP targets displayed a greater affinity for osteoblastic attachment that both the control and higher $\mathrm{Ca} / \mathrm{P}$ ratio film. Enhanced levels of cell attachment during the initial stages of interaction with a physiological environment may be interpreted as an effective response which should support cell proliferation and possible osteogenesis [38]. This was subsequently confirmed during an assessment of the expressed cell 
proliferation on these surfaces. After 7 days of cell culture, the number of viable cells on both surfaces was significantly greater than the control surface, although no statistical difference was observed between the $\mathrm{Ca}-\mathrm{P}$ surfaces. However, it was noted that at the early stages of cell culture ( 1 and 4 days) the lower $\mathrm{Ca} / \mathrm{P}$ ratio (TCP targets) demonstrated enhanced proliferation of osteoblastic cells. Morphological analysis using SEM also demonstrated appropriate levels of cell spreading at earlier time points of cell culture and throughout the study on both $\mathrm{Ca}-\mathrm{P}$ surfaces. This is highly indicative of appropriate cell attachment, and therefore can be regarded as a measure of surface biocompatibility. In addition, the nature of the surface chemistry of the lower $\mathrm{Ca} / \mathrm{P}$ ratio film may provide more suitable conditions for osteoblastic cell activity. A further interesting observation here was the change in the nature of the surface features at the very early stages of cell culture, most notably up to $60 \mathrm{~min}$. There is a clearly observed increase in the density of surface features (between $200 \mathrm{~nm}$ and $1 \mu \mathrm{m}$ in diameter) between the $30 \mathrm{~min}$ and $60 \mathrm{~min}$ stages of cell culture. This may indicate a degree of dissolution and re-precipitation of both $\mathrm{Ca}-\mathrm{P}$ coatings deposited here. Previous studies by the authors have shown that largely crystalline $\mathrm{Ca}-\mathrm{P}$ coatings can undergo dissolution even after only $1 \mathrm{~h}$ of immersion in PBS solution [15]. Given the fact that cell culture conditions represents a significantly more aggressive environment than PBS it is not inconceivable here that these Ca-P surfaces are dissolving and re-precipitating at this very early time point. A further interesting highlight of this work is the fact that the coatings both show a high degree of preferred 002 orientation (as shown by XRD analysis). Previous work by Kim et al. [39] has highlighted that such coatings can undergo dissolution and re-precipitation within a very short timeframe, such as that studied here. Indeed, the study of Kim et al. demonstrated that such a phenomenon was possible followed by homoepitaxial growth, although there is no evidence for this happening here as appropriate analysis of the surface restructuring mechanism has not been undertaken. At the $4 \mathrm{~h}$ stage of culture the coating appears to undergo further dissolution, however, the nature of this dissolution is heterogeneous in nature. In some areas the $\mathrm{Ca}-\mathrm{P}$ coatings appear to be porous in nature (along with some areas of delamination mentioned previously). However, there are also areas still showing significant spherulitic features on the surface which are still evident after $24 \mathrm{~h}$ of culture as highlighted in Fig. 9. As the surface of both of these coatings has been shown to be calcium rich, this may have been, in part, responsible for the initial dissolution of the thermally annealed coatings and appears to be consistent with nonstoichiometric (or incongruent) dissolution described in detail by Dorozhkin previously [40, 41]. This is normally the case when a surface layer has a chemical composition that is different from that of the bulk material and only ever occurs on the nano-scale [15].

The continued actions observed by cell membrane filopodia at $24 \mathrm{~h}$ of in vitro culture suggest a higher predilection of cell interactions with these TCP derived surfaces. Additionally, probing of the cell surface and attachment (before possible cell migrational behaviour) by these cell membrane protrusions appeared to interact preferentially with the surface features of the coatings (as observed at $24 \mathrm{~h}$ ). Therefore the ability to present more significant surface topography under physiological conditions may be increasing the surface functionality, which would promote cell attachment [42]. As previously demonstrated in other studies, the ability to significantly increase the surface roughness of sputter deposited $\mathrm{Ca}-\mathrm{P}$ thin films using topographically appropriate substrates could provide the ability to introduce enhanced cell attachment on these surfaces [6]. Finally the accumulations of vinculin at the cell membrane peripheries which denote the focal adhesion sites of the cell were more clearly evident on the $\mathrm{Ca}-\mathrm{P}$ surface which demonstrated a lower $\mathrm{Ca} / \mathrm{P}$ ratio (from the TCP targets). This was shown to be the case at both time points of immunofluorescent staining. These results support the attachment and cell spreading previously observed during the biological characterisation, and again indicates that $\mathrm{Ca}-\mathrm{P}$ surfaces deposited from the lower $\mathrm{Ca} / \mathrm{P}$ ratio targets (TCP targets) demonstrate a clear advantage in terms of the promotion of cell attachment and bioactivity (proliferation) compared to the more conventionally deposited surfaces (from HA targets). As stated earlier, these surfaces had a much lower $\mathrm{Ca} / \mathrm{P}$ ratio than the $\mathrm{HA}$ derived coatings, slightly lower levels of carbonate and a higher degree of preferred 002 orientation. These coatings produced from the HA targets are therefore slightly more calcium rich than the TCP surfaces. Previous studies utilising these coatings have shown that calcium rich coatings mediate the adsorption of proteins and control the subsequent cellular attachment and proliferation of osteoblast cells [31]. Notwithstanding the fact that the HA derived coating has a higher $\mathrm{Ca} / \mathrm{P}$ ratio and is more calcium rich than the TCP derived coating, it may have been expected that this coating provided a more appropriate surface to promote the initial cellular attachment and proliferation. However, this was not the case in this study, which leads the authors to suggest that the optimised $\mathrm{Ca} / \mathrm{P}$ ratio for controlling the initial cellular response, in vitro, may lie somewhere between stoichiometric $\mathrm{HA}$ and the higher $\mathrm{Ca} /$ $\mathrm{P}$ ratio obtained from the HA deposited from the HA targets. It has been reported that the bioactivity attributed to Ca-P materials originates due to the actions of free $\mathrm{Ca}^{2+}$ ions, [43] however it has been noted that an overenrichment of this environment with $\mathrm{Ca}^{2+}$ (and $\mathrm{PO}_{4}{ }^{3-}$ ) 
components can cause adverse reactions to biological tissue and host cellular activities, such as cell apoptosis $[44,45]$. Without ignoring the role of stoichiometry here, the fact that both coatings had a preferred 002 orientation (with a greater degree of 002 orientation observed in the TCP derived surface) may have allowed for an enhanced osteoblastic response. Indeed, previous work by others has shown that preferred c-axis orientation can enhance the cellular response in vitro, in particular for mesenchymal stem cells (MSC) [39]. This would also support the initial in vitro results seen here. Previously there has been debate within the literature regarding whether crystalline or amorphous coatings better support osteoblast cell growth [18]. Clearly the results here indicate that even apparent crystalline coatings are not entirely stable in vitro, but that crystalline coatings with preferred orientation (along with a specific stoichiometry) may provide a successful route to controlling the resultant biological performance of such surfaces.

Although the $\mathrm{Ca} / \mathrm{P}$ ratio and the preferred 002 orientation do appear to have a significant role to play in mediating the initial cellular response in this study, the surface topography is also important. Specifically, the interactions of the filopodia with the surface topography, observed in the SEM images, provide direct evidence for this. Additionally, the carbonate levels within the coatings could also have influenced the in vitro results observed. However, given the marginal difference in the carbonate levels recorded between the different coatings and the relatively low concentrations involved, stoichiometry and preferred orientation are more likely to have been the overriding reasons for the enhanced results of the TCP derived surfaces. Previous studies by others have shown that much higher carbonate concentrations are normally required to enhance osteoblast activity, in vitro [46].

\section{Conclusion}

The ability to predetermine $\mathrm{Ca}-\mathrm{P}$ surface properties is of the utmost importance in terms of controlling a biological response. The surface properties observed in the TCP targets were more characteristic of naturally occurring apatite. Furthermore, the TCP derived thin films, which demonstrated a preferred 002 orientation along with lower surface $\mathrm{Ca} / \mathrm{P}$ ratio and carbonate levels clearly established an enhanced osteoblastic cell response in terms of cell adhesion and cell proliferation in the earlier stages of cell culture than the surfaces deposited from the HA material. An improvement in the initial cell attachment and a potential for increased cell proliferation rates is viewed as a highly advantageous result in relation to controlling the osteoblast response on these surfaces. Therefore, the work highlighted here shows that engineering specific characteristics into these sputter deposited coatings represents a direct way to influence subsequent cell-surface interactions. What is very apparent here is the need to control both the surface chemistry and the surface topography when trying to influence the initial osteoblast response, as both are important in this regard. The critical aspects of this work highlight that small differences in surface properties, namely stoichiometry and c-axis orientation can have a significant influence on the subsequent biological response, something that needs to be carefully considered when designing such surfaces in the future.

Acknowledgments The authors would like to acknowledge the PhD funding provided by the Department of Education and Learning Northern Ireland to support his work.

\section{References}

1. Surmanev RA. A review of plasma-assisted methods for calcium phosphate-based coatings fabrication. Surf Coat Tech. 2012;206: 2035-56.

2. Kaciulis S, Mattogno G, Pandolfi L, Cavalli M, Montenero A, Gnappi G. XPS study of apatite-based coatings prepared by solgel technique. Appl Surf Sci. 1999;151:1-5.

3. Gottlander M, Johansson CB, Wennerberg A, Albrektsson T, Radin $\mathrm{S}$, Ducheyne P. Bone tissue reactions to an electrophoretically applied calcium phosphate coating. Biomaterials. 1997;18:551-7.

4. Kokubo T. Formation of biologically active bone-like apatite on metals and polymers by a biomimetic process. Thermochim Acta. 1996;280(281):479-90.

5. O'Hare P, Meenan BJ, Burke GA, Byrne G, Dowling D, Hunt JA. Biological responses to hydroxyapatite surfaces deposited via a coincident microblasting technique. Biomaterials. 2010;31:512-22.

6. Boyd AR, Burke GA, Duffy H, Cairns ML, Meenan BJ. Characterisation of calcium phosphate/titanium dioxide hybrid coatings. J Mater Sci Mater Med. 2008;19:485-98.

7. Ueda $K$, Narushima $T$, Goto $T$, Katsube $T$, Nakagawa $H$, Kawamura H, Taira M. Evaluation of calcium phosphate coating films on titanium fabricated using RF magnetron sputtering. Mater Trans. 2007;3:307-12.

8. Thian ES, Huang J, Best SM, Barber ZH, Bonfield W. Surface modification of magnetron-sputtered hydroxyapatite thin films via silicon substitution for orthopaedic and dental applications. Surf Coat Technol. 2011;205:3472-7.

9. van Dijk K, Schaeken HG, Wolke JGC, Maree CHM, Habraken FHPM, Verhoeven J, Jansen JA. Influence of discharge power level on the properties of hydroxyapatite films deposited on Ti6A14V with RF magnetron sputtering. J Biomed Mater Res. 1995;29:269-76.

10. Yonggang Y, Wolke JGC, Yubao L, Jansen JA. The influence of discharge power and heat treatment on calcium phosphate coatings prepared by RF magnetron sputtering deposition. J Mater Sci: Mater Med. 2007;18:1061-9.

11. Boyd AR, Duffy H, McCann R, Cairns ML, Meenan BJ. The Influence of argon gas pressure on co-sputtered calcium phosphate thin films. Nucl Instrum Meth B. 2007;258:421-8.

12. van Dijk K, Schaeken HG, Maree CHM, Verhoeven J, Wolke JGC, Habraken FHPM, Jansen JA. Influence of Ar pressure on R.F. magnetron-sputtered $\mathrm{Ca}_{5}\left(\mathrm{PO}_{4}\right)_{3} \mathrm{OH}$ layers. Surf Coat Technol. 1995;76-77:206-10. 
13. Boyd AR, Duffy H, McCann R, Meenan BJ. Sputter deposition of calcium phosphate/titanium dioxide hybrid thin films. Mater Sci Eng C. 2008;28:228-36.

14. Ozeki K, Yuhta T, Fukui Y, Aoki H. Influence of the calcium phosphate content of the target on the phase composition and deposition rate of sputtered films. Appl Surf Sci. 2007;253:5040-4.

15. O'Kane C, Duffy H, Meenan BJ, Boyd AR. The influence of target stoichiometry on the surface properties of sputter deposited calcium phosphate thin film. Surf Coat Technol. 2008;203:121-8.

16. Surmeneva MA, Chaikina MV, Zaikovskiy VI, Pichugin VF, Buck V, Prymak O, Epple M, Surmenev RA. The structure of an RF-magnetron sputter-deposited silicate-containing hydroxyapatite-based coating investigated by high-resolution techniques. Surf Coat Technol. 2013;218:39-46.

17. Ozeki K, Hoshino T, Aoki H, Masuzawa T. Phase composition of sputtered film from a mixture of hydroxyapatite and strontiumapatite. J Mater Sci Technol. 2013;29:1-6.

18. Thian ES, Huang J, Best SM, Barber ZH, Bonfield W. Magnetron co-sputtered silicon-containing hydroxyapatite thin films-an in vitro study. Biomaterials. 2005;26:2947-56.

19. Kong D, Wu Y, Long D, Zhou C. Mechanical properties of hydroxyapatite-zirconia coatings prepared by magnetron sputtering. Trans Nonferrous Met Soc China. 2012;22:104-10.

20. Ligot S, Godfroid T, Music D, Bousser E, Schneider JM, Snyders R. Tantalum-doped hydroxyapatite thin films: synthesis and characterization. Acta Materialia. 2012;60:3435-43.

21. Chen W, Liu Y, Courtney HS, Bettenga M, Agrawal CM, Bumgardner JD, Ong JL. In vitro anti-bacterial and biological properties of magnetron co-sputtered silver-containing hydroxyapatite coating. Biomaterials. 2006;27:5512-7.

22. Boyd AR, O'Kane C, Meenan BJ. Control of calcium phosphate thin film stoichiometry using multi-target sputter deposition Control of calcium phosphate thin film stoichiometry using multitarget sputter deposition Control of calcium phosphate thin film stoichiometry using multi-target sputter deposition Control of calcium phosphate thin film stoichiometry using multi-target sputter deposition. Surf Coat Tech in Press 2013. doi: 10.1016/ j.surfcoat.2013.04.017.

23. Takahashi K, van den Beucken JJJP, Wolke JGC, Hayakawa T, Nishiyama N, Jansen JA. Characterization and in vitro evaluation of biphasic calcium pyrophosphate-tricalciumphosphate radio frequency magnetron sputter coatings. J Biomed Mater Res. 2008;84(3):682-90.

24. Boyd AR, Meenan BJ, Leyland NS. Surface characterisation of the evolving nature of radio frequency (RF) magnetron sputter deposited calcium phosphate thin films after exposure to physiological solution. Surf Coat Tech. 2006;200:6002-13.

25. Boyd AR, Akay M, Meenan BJ. Influence of target surface degradation on the properties of rf magnetron-sputtered calcium phosphate coatings. Surf Inter Anal. 2003;35:188-98.

26. Vignoles M, Bone G, Young RA. Occurrence of nitrogenous species in precipitated B-type carbonated hydroxyapatites. Calcif Tissue Int. 1987;40:64-70.

27. Holt C, van Kemenade M, Nelson LS, Harries JE, Bailey RT, Hukins DWL, Hasnain SS, De Bruyn PL. Amorphous calcium phosphates prepared at $\mathrm{pH} 6.5$ and 6.0. Mater Res Bull. 1989;24:55-62.

28. Ha SW, Kirch M, Birchler MF, Eckert KL, Mayer J, Wintermantel E, Sittig C, Pfund-Klingenfuss I, Textor M, Spencer ND. Surface activation of polyetheretherketone (PEEK) and formation of calcium phosphate coatings by precipitation. J Mater Sci Mater Med. 1997;8:683-90.

29. Ong JL, Hoppe CA, Cardenas HL, Cavin R, Carnes DL, Sogal A, Raikar GN. Osteoblast precursor cell activity on HA surfaces of different treatments. J Biomed Mater Res Part A. 1998;39:176-83.

30. Ong JL, Lucas LC, Raikar GN, Weimer JJ, Gregory JC. Surface characterization of ion-beam sputter-deposited Ca-P coatings after in vitro immersion. Coll Surf A Physiochem Eng Asp. 1994;87:151-62.

31. Cairns ML, Meenan BJ, Burke GA, Boyd AR. Influence of surface topography on osteoblast response to fibronectin coated calcium phosphate thin films. Coll Surf B. 2010;78:283-90.

32. Wopenka B, Pasteris JD. A mineralogical perspective on the apatite in bone. Mater Sci Eng. 2005;C25:131-43.

33. Tang Q, Brooks R, Rushton N, Best S. Production and characterization of HA and SiHA coating. J Mater Sci Mater Med. 2010;21:173-81.

34. Gibson IR, Bonfield WJ. Novel synthesis and characterization of an AB-type carbonate-substituted hydroxyapatite. Biomed Mater Res. 2002;59:697-708.

35. Vallet-Regí M, González-Calbet JM. Calcium phosphates as substitution of bone tissues. Progress Solid State Chem. 2004;32:1-31.

36. Guo Y, Yao Y, Ning C, Guo L, Chu L. Fabrication of mesoporous carbonated hydroxyapatite microspheres by hydrothermal method. Mater Lett. 2011;65:2205-8.

37. Magne D, Pilet P, Weiss P, Daculsi G. Fourier transform infrared microspectroscopic investigation of the maturation of nonstoichiometric apatites in mineralized tissues: a horse dentin study. Bone. 2001;29:547-52.

38. Yang Y, Tian J, Deng L, Ong JL. Morphological behavior of osteoblast-like cells on surface-modified titanium in vitro. Biomaterials. 2002;23:1383-9.

39. Kim H, Camata RP, Chowdhury S, Vohra YK. In vitro dissolution and mechanical behavior of c-axis preferentially oriented hydroxyapatite thin films fabricated by pulsed laser deposition. Acta Biomaterialia. 2010;6:3234-41.

40. Dorozhkin SV. Surface reactions of apatite dissolution. J Colloid Interface Sci. 1997;191:489-97.

41. Dorozhkin SV. A review on the dissolution models of calcium apatites. Prog Cryst Growth Charact Mater. 2002;44:45-61.

42. Anselme K, Bigerelle M, Noel B, Dufresne E, Judas D, Lost A, Hardouin PJ. Qualitative and quantitative study of human osteoblast adhesion on materials with various surface roughnesses. Biomed Mater Res Part A. 2000;49:155-66.

43. Geesink RG, de Groot K, Klein CP. Bonding of bone to apatitecoated implants. J Bone Joint Surg Br. 1988;70B:17-22.

44. Suzuki T, Yamamoto T, Toriyama M, Nishizawa K, Yokogawa Y, Mucalo MR, Kawamoto Y, Nagata F, Kameyama T. Surface instability of calcium phosphate ceramics in tissue culture medium and the effect on adhesion and growth of anchoragedependent animal cells. J Biomed Mater Res. 1997;34:507-17.

45. Yamada S, Heymann D, Bouler JM, Daculsi G. Osteoclastic resorption of calcium phosphate ceramics with different hydroxyapatite/ $\beta$-tricalcium phosphate ratios. Biomaterials. 1997; 18:1037-41.

46. Pieters IY, Van den Vreken NMF, Declercq HA, Cornelissen MJ, Verbeeck RMH. Carbonated apatites obtained by the hydrolysis of monetite: Influence of carbonate content on adhesion and proliferation of MC3T3-E1 osteoblastic cells. Acta Biomaterialia. 2010;6:1561-8. 